Florida International University FIU Digital Commons

\title{
Investigating Vocabulary Abilities in Bilingual Portuguese-English-Speaking Children
}

Ana Paula Fabian

Florida International University, afabi001@fiu.edu

DOI: $10.25148 /$ etd.FIDC000765

Follow this and additional works at: https:// digitalcommons.fiu.edu/etd

Part of the Bilingual, Multilingual, and Multicultural Education Commons, and the First and Second Language Acquisition Commons

\section{Recommended Citation}

Fabian, Ana Paula, "Investigating Vocabulary Abilities in Bilingual Portuguese-English-Speaking Children" (2016). FIU Electronic Theses and Dissertations. 2557.

https://digitalcommons.fiu.edu/etd/2557 


\section{FLORIDA INTERNATIONAL UNIVERSITY}

Miami, Florida

\section{INVESTIGATING VOCABULARY ABILITIES IN BILINGUAL PORTUGUESE-ENGLISH-SPEAKING CHILDREN}

A thesis submitted in partial fulfillment of

the requirements for the degree of

\section{MASTER OF ARTS}

in

\section{LINGUISTICS}

by

Ana Paula Fabian 
To: Dean Michael R. Heithaus

College of Arts, Sciences and Education

This thesis, written by Ana Paula Fabian, and entitled Investigating Vocabulary Abilities in Bilingual Portuguese-English-Speaking Children, having been approved in respect to style and intellectual content, is referred to you for judgment.

We have read this thesis and recommend that it be approved.

$\begin{array}{r}\hline \text { Shannon Pruden } \\ \hline \text { Firginia C. Mueller Gathercole, Major Professor }\end{array}$

Date of Defense: July 08, 2016

The thesis of Ana Paula Fabian Freire is approved.

\begin{tabular}{r} 
Dean Michael R. Heithaus \\
College of Arts, Sciences, and Education \\
\hline Andrés G. Gil \\
resident for Research and Economic Development \\
and Dean of the University Graduate School
\end{tabular}

Vice President for Research and Economic Development andean of the University Graduate School

Florida International University, 2016 


\section{DEDICATION}

I dedicate this thesis to my children, Giulia and Leonardo, who are my inspiration, and to my husband Marcelo, for his love and encouragement throughout this time. 


\section{ACKNOWLEDGMENTS}

First and foremost, I would like to thank my thesis advisor, Dr. Virginia C. Mueller Gathercole for her constant support, patience and guidance throughout this process. I am deeply grateful for all her words of encouragement, for the continuous assistance, and invaluable advice. Without her direction, the completion of this work would not have been possible.

I would also like to thank my committee members, Dr. Shanon Pruden and Dr. Feryal Yavas for their support and advice as I carried out this project. A special thanks to Dr. Feryal Yavas for guiding me during graduation and helping me choose the right path. I will be forever grateful to you. Many thanks to Dr. Elizabeth Reis Teixeira for sharing her work on the Portuguese CDI with me. I would like to thank Dr. Dale for his advice with the use of the CDIs and Brookes Publishing for granting me permission to use the CDIs.

I wish to thank Lilian McLeod for her help with the translation of the background questionnaire from English to Portuguese, and for always answering all of my questions. My sincere thanks to my dear friends Alaa Jassomah, Natasha Neckles, and Samia DeCubas for their continuous support and good humor. I would also like to thank Carolyn Baker, Kelly Millard, Salvatore Callesano, Gina Ailanjian, and Daniel Garzon for their friendship, for the laughs shared in the Linguistics lab, and for their help with the recruitment of participants. I would like also to thank my family and all of my friends for helping me recruiting participants in Brazil. A special thanks to Isolda and Hans who encouraged me to launch this quest. And I would like to give a special thanks to all the parents who took their time to participate in this project. 


\title{
ABSTRACT OF THE THESIS \\ INVESTIGATING VOCABULARY ABILITIES IN BILINGUAL PORTUGUESE-ENGLISH-SPEAKING CHILDREN
}

\author{
by
}

\section{Ana Paula Fabian}

Florida International University, 2016

\section{Miami, Florida}

\section{Professor Virginia C. Mueller Gathercole, Major Professor}

This study investigated the vocabulary abilities of bilingual Portuguese-Englishspeaking children compared to their monolingual peers. Parental Report Surveys were conducted using the MacArthur-Bates Communicative Development Inventories (CDIs), which are standardized norms for vocabulary assessment. Electronic versions of the "Words and Sentences CDI" in English and Brazilian-Portuguese were used in order to assess the vocabulary of children between the ages of 16 and 36 months. Parents answered the surveys online.

Different vocabulary score types were used in order to evaluate the children's lexicons: The Total Vocabulary score, the Conceptual Vocabulary scores, and the Total Modified Vocabulary. The analyses of the results showed that bilinguals had fewer words than the monolinguals in each language separately, but no significant differences between bilinguals and monolinguals when the two languages of the bilinguals were compared together to the monolinguals'. An analysis of cognates and translation equivalents showed that cognates help with the acquisition of words. 


\section{TABLE OF CONTENTS}

CHAPTER

PAGE

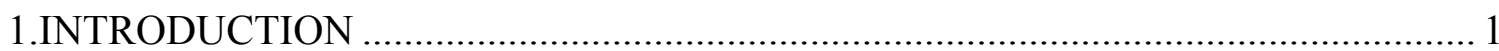

2.LITERATURE REVIEW .............................................................................. 3

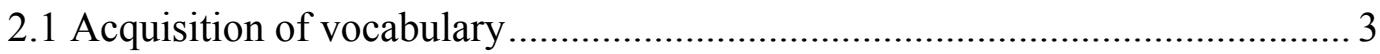

2.2 Differences and similarities between bilingual and monolingual word

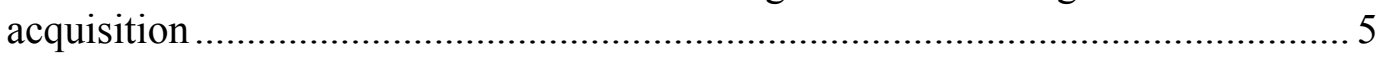

2.3 Bilingualism and Bilinguals................................................................ 7

2.4 Use of parental reports to assess vocabulary ............................................. 9

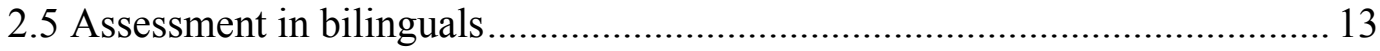

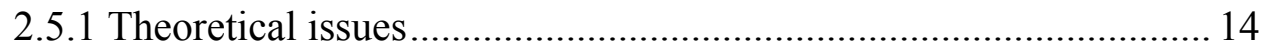

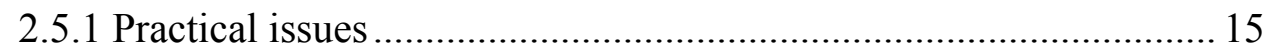

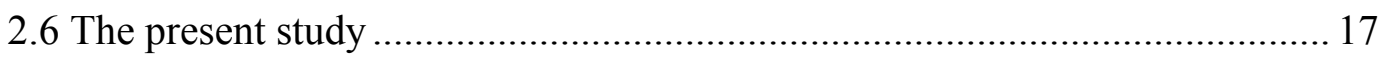

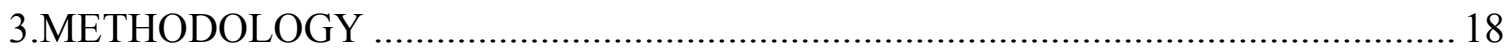

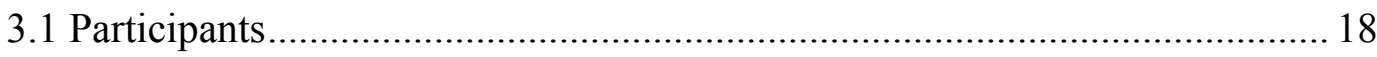

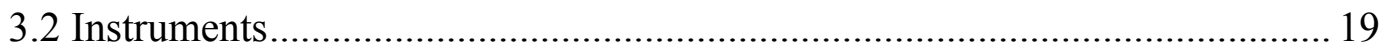

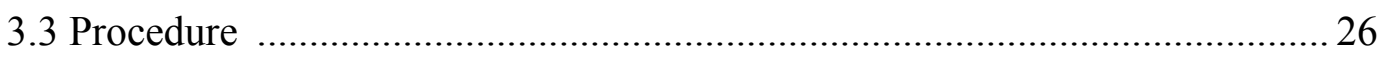

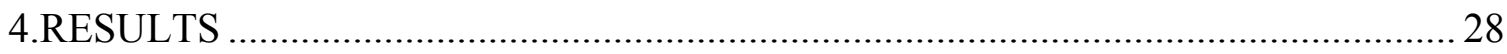

4.1 Bilingual vs Monolingual ................................................................. 28

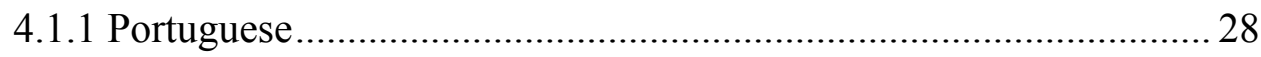

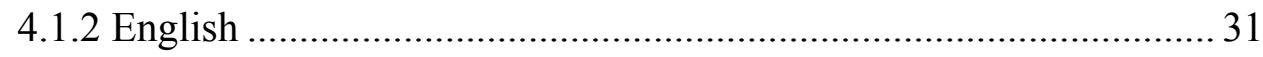

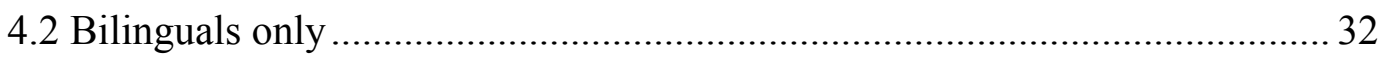

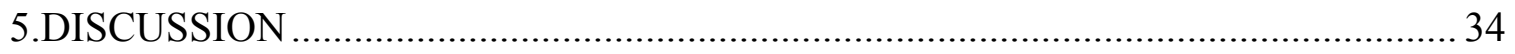

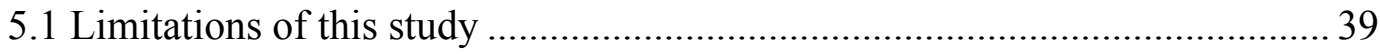

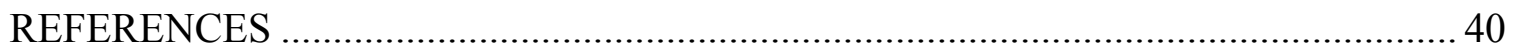

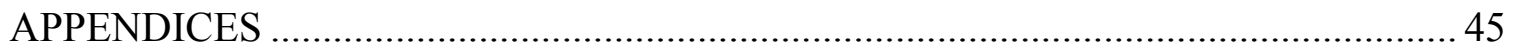




\section{INTRODUCTION}

The purpose of this study is to investigate the vocabulary knowledge of bilingual Portuguese-English-speaking children compared to their monolingual peers, speakers of English and Portuguese. The goal is to examine patterns of vocabulary acquisition in language development in children exposed to those two languages. We will examine the Total Vocabulary (TV) of bilinguals as well as their Total Conceptual Vocabulary (TCV) in comparison to those of monolinguals. We expect that cognate words will facilitate acquisition of similar elements by bilinguals in their two languages.

Language acquisition is one of the most important phases of a child's development (O'Grady, 2010) and an essential part of it involves a child's acquisition of vocabulary. The number of words a child speaks or understands is a sign of development that most pediatricians, researchers, and speech pathologists use to evaluate a child's language abilities.

As explained by Gatt, O’Toole, and Haman (2015), comparing the productive vocabulary of children that are exposed to more than one language can promote insights as to whether scores are specific to the language pair being studied or are common to other bilingual settings as well.

This study intends to assess the vocabulary abilities of bilingual PortugueseEnglish speaking children in comparison to monolingual English and monolingual Portuguese speaking children, from ages ranging from 16 months to 36 months. There is a growing population of bilingual Portuguese-English children; however, many issues regarding bilingual language acquisition for these speakers remain unstudied, especially within the age range mentioned above, and within the realm of vocabulary acquisition. 
Information on bilingual children's acquisition of vocabulary can provide insights to the following questions we will try to answer in this study:

1. Will bilingual Portuguese-English speaking children have similar patterns as those of other populations of bilingual children? Do they have translation pairs (Translation Equivalents) or do they avoid translation pairs? What proportion of their words are Translation Equivalents?

2. Do bilingual children perform better with the cognates as opposed to noncognate TEs? How much does form-similarity matter for children's performance on words?

3. What is the best way to incorporate the fact that these children are bilingual in order to assess them?

This thesis contains five chapters. After this introduction (Chapter 1), Chapter 2 consists of the literature review, Chapter 3 presents the methodology adopted for this study, in Chapter 4 the results are presented followed by the data analysis, and finally Chapter 5 presents a discussion on the topics covered in this study. 


\section{LITERATURE REVIEW}

In the review of the literature, I will examine topics relevant for this study: the acquisition of the lexicon, differences between bilinguals and monolinguals, bilingualism, and parent reports as a tool for vocabulary assessment.

\subsection{Acquisition of vocabulary}

When a child is learning two languages, his or her attention is focused on more than one lexicon (Pearson, 2008). If the aspect of acquisition being assessed is frequencydependent, bilinguals might score lower than monolinguals (Genesee and Nicoladis, 2006), because bilingual children hear less of both languages when compared to what a monolingual child hears. Among those items that require exposure to be learned is vocabulary. The amount of exposure a child receives in each language will affect his/her vocabulary size (Hoff, Core, Place, Rumiche, Señor, \& Parra, 2012) and the vocabulary knowledge will be distributed across languages (Gatt, O’Toole, \& Haman, 2015; Gathercole \& Thomas, 2009). Bilingual children might score a little below the norms in each of their languages when vocabulary size is analyzed for each language separately (Hoff et al, 2012; Gathercole \& Thomas, 2009). (See below for a discussion of Total Vocabulary score and Total Conceptual Vocabulary score).

For monolinguals and bilinguals, many early language milestones are similar, regardless of which language children are learning, or how many languages they are learning (Pearson, 2009). De Houwer (2012) explains that there are specific milestones for bilinguals that should be considered, in addition to the universal milestones that are well known and should also be considered for all children. The milestones that are 
important for all children: babbling (at around 6 months), language comprehension (at around 9 months), first words (at around 12 months), first 50 words (between 18 and 24 months), and short sentences (by the age of 3 years) are reached at about the same time for monolinguals and bilinguals (O’Toole, 2013; Pearson, 2008).

Pearson (2008) describes that between 6 to 9 months, babies turn towards their name and they can start producing their first syllables, like 'dadada', 'bababa'. At around 12 months, babies start to recognize words for things that interest them, and some might have started saying a few words. At 16 months, the receptive vocabulary averages 140 (for boys) and 190 (for girls). At 18 months, the average expressive vocabulary for a boy is 75 words, and for girls, 112 words $^{1}$. By 24 months, the child understands most of what is spoken to her and a major milestone is reached: two-word combinations, which emerged around the fifty-word mark. Around 36 months of age, children understand much more of the language spoken to them and can follow two-step directions. They are able to speak in simple sentences, although sometimes not intelligibly. De Houwer (2012) and Genesee and Nicoladis (2006) also maintain that monolinguals and bilinguals do not differ at the ages at which these milestones are reached.

Comprehension in both languages and development of two separate grammatical systems are milestones important only to bilinguals (De Houwer, 2012), therefore there is need for an assessment that considers these bilingual characteristics.

\footnotetext{
${ }^{1}$ Pearson explains that gender differences observed become less evident by school age. These data are from a standard parent report form.
} 


\subsection{Differences and similarities between bilingual and monolingual word acquisition}

In studying bilinguals, one question that frequently comes to mind is that of a bilingual advantage or disadvantage in comparison to monolinguals. It is important to clarify, as explained by Hoff, Core, Place, Rumiche, Señor, \& Parra (2012), that there are not any serious and current claims saying that bilingual children are confused or slower than monolinguals in their ability to learn a language. For Thordardottir (2005), development in more than one language is different in some ways from monolingual development, but it is not more difficult. If fact, many studies that have measured both lexicons of bilingual children showed that they look very similar to those of monolinguals (Pearson and Fernandez, 1994; Patterson and Pearson, 2004). In a study with French-English bilinguals compared to monolinguals, Poulin-Dubois, Bialystok, Blaye, Polonia, and Yott, (2013) found significant differences between monolingual and bilinguals' expressive vocabulary size in their L1, but similar total vocabularies (TV).

According to Gathercole (2002), bilinguals will likely be different than monolinguals in quantitative measures, such as inventories of words in terms of production, especially when compared within a language in which they have not reached a threshold of enough input; in this case, the bilinguals will score lower than monolinguals (Pearson, 2013). This threshold is a proposed mechanism that would allow bilinguals and monolinguals' inventories to be equivalent, independent of the amount of input (Gathercole, 2002). However, it is not yet possible to predict thresholds for different constructions of different complexities in different languages (Pearson, 2013). 
When considering the differences between bilinguals and monolinguals, it is also important to take into consideration the distributed characteristics of bilinguals' language knowledge and experience, a characteristic that is not relevant to monolinguals. According to Oller (2005), in some instances, the vocabulary of a bilingual tends to be available in one language without a translation equivalent available in the other language, hence the term 'distributed' across the two languages. This distributed characteristic might prove to be a problem in case a bilingual is being assessed using strictly monolingual norms, as the whole lexicon of the bilingual will not be available for the single-language assessment. For example, a bilingual child might know certain words used to name family members (aunt, uncle, cousin, etc.) in her home language because that is the language in which those words are used. However, at the daycare not many of those words to name family members are used, so the child does not know those words in the dominant language. In contrast, the child might know the names of the shapes and colors, for example, in the school language because that is what the teachers and caregivers use, but she might not know those words in her home language, because her parents never talk about those items.

Because language in bilinguals is distributed across two languages, the issue of what "counts" for vocabulary knowledge in bilinguals has been the focus of much research. Some have proposed that what needs to be examined is the "Total Conceptual Vocabulary" of bilinguals. The Total Conceptual Vocabulary (TCV) scores are the number of concepts produced or understood by children in either language, whereby Translation Equivalents - corresponding words or expressions in the two languages (TEs) are only counted once (O'Toole, 2013). Others have argued that, for comparisons 
of monolinguals and bilinguals, the use of both TCV and Total Vocabulary (TV) is needed (Gatt et al., 2015). The Total Vocabulary scores are the total number of words produced in both languages by children. Bosch and Ramon-Casas (2014) agree that the measurement of combined vocabulary scores results in a more accurate account of bilingual lexicons. Also important for studies involving vocabulary acquisition in bilinguals, are the cognates, words that have the same etymological origin, and share an identical or similar meaning, spelling or pronunciation. Research shows that early lexical acquisition in the two languages can be increased by cognates (Bosch \& Ramon-Casas, 2014). The so called cognate facilitation effect has been already established by studies on bilingual word recognition. (Dijkstra, Miwa, Brummelhuis, Sappelli, \& Baayen, 2010).

\subsection{Bilingualism and Bilinguals}

Bilingual children and adults vary widely in their experiences in their two languages and in the level of proficiency in each of their languages. While a bilingual is, arguably, an individual who is able to speak competently - or fluently - at least two languages, the range of variation in language experience in bilinguals is vast (Gathercole, 2014). As Pearson (1998) says, by definition, a bilingual has (some) knowledge of two languages. Grosjean (2013) defines bilingualism as "the use of two or more languages (or dialects) in everyday life" (p. 5). Bialystok (2001) explains that, at best, bilingualism can be put on a scale, starting from no awareness of a second language to complete mastery of two languages. Moreover, bilingual children are from a variety of backgrounds and different environments. They differ in the age at which they start learning their two 
languages, in the situations in which they use each language, and in the extent of the motivations they have to learn each of their languages (Thordardottir, 2005).

The simultaneous acquisition of two languages from birth is called Bilingual First Language Acquisition (BFLA) (Genesee and Nicoladis, 2006), whereas the learning of another language after the first is well established is called early Second Language Acquisition (early SLA) (Pearson, 2009). According to Pearson, those two groups are considered early bilinguals, in the sense that they will have native-like skills, although the simultaneous BFLA will occur from birth, while the early SLA will start after the ages of 2 or 3 years, following the establishment of the first language (L1). In comparison, a late bilingual will have non-native or near-native skills in his/her second language (L2). Children learning two languages sequentially will have a first language (L1) and a second language (L2).

Therefore, there are different types of bilinguals depending on when they have had the first contact with their languages: simultaneous and sequential (or consecutive) bilinguals. Simultaneous bilinguals are those who learn two languages from birth, as opposed to sequential bilinguals, who learn one language before the other (Pearson, 2008). Even 'simultaneous' bilinguals may become more proficient in one language than the other (Genesee and Nicoladis, 2006; Gathercole and Thomas, 2009). And even a sequential bilingual, as an early learner, can learn both languages in the same manner of the first language acquired.

With enough and rich language interactions in their two languages, children can learn two languages easily and without explicit formal instruction (Pearson, 2009). Children's relative dominance in each language can change over time as a result of 
changes in the child's exposure to each language (Genesee and Nicoladis, 2006). Pearson (2013) believes that length of exposure to a language might be best to determine expected levels of performance, rather than the typical practice of using the chronological age of a child. However, for the purposes of this study chronological age will be the basis for the assessment. It is also important to notice that, in bilinguals, one of the languages of the bilingual is typically dominant, while the other is non-dominant, or weaker. However, that can change over time, depending on the needs for one language or the other (Pearson, 2009).

De Houwer (2005) states that frequency of input is crucial in both monolingual and bilingual children, but more important in a bilingual environment. The more words children hear in the early years, the larger will be their lexicons (Cartmill, Armstrong III, Gleitman, Goldin-Meadow, Medina, \& Trueswell, 2013). The amount of exposure of each language can affect the relative performance of bilingual children (Gathercole, Thomas, Roberts, Hughes, \& Hughes, 2013) and also their vocabulary size (Pearson, 1998).

\subsection{Use of parental reports to assess vocabulary}

The MacArthur Bates Communicative Development Inventories - CDIs (Fenson, Dale, Reznick, Thal, Bates, Hartung, Pethick, \& Reilly, 1993) are a popular tool that has gained favor across languages over the last three decades. These consist of parental reports; the original reports, developed for English, were adapted from early works of Elizabeth Bates and her colleagues (Fenson, Marchman, Thal, Dale, Reznick \& Bates, 2007). 
The norming for the first CDIs (http://childes.psy.cmu.edu/tools/CDI/) was based on an original sample of 671 infants and 1,142 toddlers (Fenson et al., 2007). The norms were created centered on guidelines established to assure the validity of the inventories. In a later updated sample, the participants were screened taking into consideration medical exclusionary criteria (excluding children born 6 or more weeks prematurely, having repeated ear infections, or reporting any serious medical condition). The total number of children in the updated sample was 1,089 infants and 1,461 toddlers. Maternal education and ethnicity, birth order, and exposure to a second language were also taken into account in order to expand the diversity of the sample, including the sites of data collection - New Haven, San Diego, and Seattle (Fenson et al., 2007).

The CDIs were designed to be completed by parents or main caregivers, in order to minimize the limitations of language samples and controlled tests (Fenson et al., 2007), which are time-consuming and can limit the number of children observed. O'Toole (2013) comments that language sampling has the disadvantage of being time-consuming and also restrictive in terms of the language structures observed; such records of free speech might also underestimate the verbal abilities of the child (Bornstein and Haynes, 1998).

Because they do not require child cooperation, parent reports can be used to evaluate infants and toddlers who might be reluctant to interact with strangers or who might not be willing to cooperate during tests (Feldman, Dollaghan, Campbell, KursLasky, Janosky, \& Paradise, 2000; Fenson et al., 2007). A child's performance in a laboratory or clinical setting might be highly influenced by aspects of the child's personality. As Fenson et al. (2007) suggest, clinicians could also use parent reports as a 
supplement to check the validity of their own assessments, being especially valuable in monitoring language development over time.

The use of parental reports for vocabulary assessment is seen as advantageous because they rely on the recognition of vocabulary items, rather than the recollection of them (Gatt et al., 2015; Fenson et al., 2007). They focus on current and emerging behaviors and avoid retrospective accounts of language. Moreover, because a parent has the opportunity to observe the child in a varied range of situations, the data collected can be more representative of the actual language of the child (Fenson et al., 2007).

Because of the format and its strict criteria, the CDIs have proven to be a reliable and valid tool for assessment of language in infants and toddlers (Jackson-Maldonado, Marchman, Thal, Bates, \& Gutiérrez-Clellen, 1993). The CDIs have been used significantly in studies involving language skills of infants and toddlers, for both normal language processes and language processes of populations with special needs (Heilmann, Weismer, Evans, \& Hollar, 2005).

The CDIs have been invaluable in studies of normally developing infants and toddlers, but also, as explained in the updated 'User's guide and Technical Manual' (Fenson et al., 2007), the CDIs can also be used for both clinical and research applications: to identify children at risk for a language delay and evaluate older children with language delay, to identify some of the aspects of the child's communication skills for intervention, to monitor changes after treatment, to screen and preselect children at different levels of language development to be included in research studies, and to examine the influence of other variables on language development, among others. 
As will be explained in detail in the Methodology Section, Chapter 3, the CDIs are divided into 3 classes: CDI Words and Gestures (to be used with infants, ages 8-16 months); CDI Words and Sentences (toddler form, 16-30 months); and the MacArthurBates Communicative Development Inventory-III (CDI-III), for ages between 30 and 37 months. The value of the CDIs is demonstrated by the fact that these forms have been adapted to different languages (Dale \& Penfold, 2011), such as Spanish (JacksonMaldonado et al., 1993), Italian (Caselli \& Casadio, 1995), Swedish (Berglund \& Eriksson, 1996), Irish (O’Toole \& Fletcher, 2008), Basque (Almgrem, Ezeizabarrena, \& Garcia, 2007), Maltese (Gatt, 2007), among others. The CDIs have also been adapted to Brazilian Portuguese in the two forms "CDI Words and Gestures" (Silva, 2003) and "CDI Words and Sentences" (Teixeira, 2005), although these have not been normed.

Silva (2006) explains that the Portuguese versions of the CDIs do not consist of simple translation, but rather the researchers underwent a process of adaptation of the CDIs in order to make it a valid and efficient linguistic developmental measure also to be applied to the Brazilian Portuguese population, as oriented by the International Project Coordination, and considering the linguistics and cultural differences between the countries where the languages are spoken (Dale \& Penfold, 2011).

Because the CDI adaptations have been created for many languages, it represents a step forward for the assessment of bilingual children, in that it allows for crosslinguistic assessment of those children, as seen in O'Toole (2013) with Irish-English bilinguals.

It should be noted that not all of the aspects of the CDIs have had a positive review. Even Fenson et al. (2007) recognize that parent reports have their limitations, as 
parents might under- or overestimate their children's language abilities. Feldman et al. (2000) also report that in the original CDI norming, parents with low educational and income levels, who were underrepresented in the CDI norming sample, apparently overestimated their children's language abilities, when compared to parents of higher educational and income levels. Fenson, Marchman, Thal, Dale, Reznick, \& Bates (2010) concur that CDI norming studies suggest that some lower-income parents overestimate or over-report certain language skills, mainly in infancy. However, the findings do not mean the CDIs should not be used to assess children from low-income households (Fenson et al., 2010). Another limitation mentioned by Core, Hoff, Rumiche, \& Señor (2013) is related to the accuracy of the parent report for bilingual children: the parents might not know all the words the child says in both languages. In this case, it is suggested that another person completes the inventory, which might not be always practical.

Nevertheless, to date, the CDIs are considered by many to be one of the most reliable and convenient tools to measure vocabulary in children. As explained by Fenson and colleagues (2010), the existence of such instruments to assess vocabulary and, consequently, language abilities permit cross-linguistic questions to be investigated with large sample sizes.

\subsection{Assessment in bilinguals}

For Hoff (2009), bilingual children have distinctive strengths in each of their languages, so it is important to be able to assess those strengths accurately. Thordardottir (2005) states that assessment of language proficiency has to take both languages into account, carefully considering the amount of input received in each language. Many 
researchers agree that we do not - yet - have satisfactory norms to assess bilinguals in many areas of language development, especially vocabulary acquisition (Pearson, 2008; De Houwer et al., 2014). For lexical assessment, monolingual norms are usually 'borrowed' and sometimes adapted to fulfil the needs for bilingual assessment, which is the case for the CDIs.

For the present study, in the absence of a bilingual Communicative Development Inventory to assess Portuguese-English bilinguals, the two versions of the CDIs for English and for Brazilian Portuguese are used. Although not without the issues cited above, the CDIs seem to be a reliable tool to assess vocabulary in bilingual infants and toddlers, as research has shown its validity for this purpose: Marchman and MartínezSussman (2002), for Spanish-English bilinguals; De Houwer et al. (2014), for FrenchDutch bilinguals; O’Toole (2013), for Irish-English bilinguals.

\subsubsection{Theoretical issues}

The investigation of vocabulary abilities in monolingual speakers of a language has been well documented. This is especially true for English: according to Hoff (2009) there is more research describing monolingual children acquiring English than any other language or group. With the exception of the adaptation of the CDIs to Brazilian Portuguese (Teixeira, 2005; Silva, 2003), studies specifically on Brazilian Portuguese involving quantitative or experimental research on vocabulary acquisition in infants and toddlers are rare. Even the milestones for the language are described based on those of English speakers, for example, or are based on a review of literature in English (Gândara \& Befi-Lopes, 2010). 
There are important theoretical issues that can be addressed in the examination of bilingual children's language development. Cross-linguistic studies of language acquisition in bilingual children can give us a better understanding of the processes and mechanisms of language development (Slobin, 2006). We can also learn how the two languages interact, or even what controls the sequence of development. According to De Houwer et al. (2014), it is important to assess different language combinations in order to address whether bilingual-monolingual similarities and differences are consistent across diverse language-pairs.

\subsubsection{Practical Issues}

There are practical ramifications of studying acquisition in bilinguals as well. Most relevant are the issues that concern assessment of language abilities in bilingual children. Much of what we know today is based on monolingual norms (Pearson, 2008), and researchers have argued that bilingual children should not be evaluated according to monolingual norms because the scores will not reflect the real abilities of the children in the languages (Pearson, 1998; Hoff et al., 2012).

Pearson (1998) advocates that it is important to have the right instruments to assess language development in bilinguals in order to have reliable results. Bilingual norms can add to the knowledge of language development in bilingual children, as well as identify new - or corroborate existent - milestones for that group. Norms for assessment of bilinguals would also facilitate the identification of young bilingual children at risk for language delay. According to Fenson et al. (2007), norms for assessment of language can be used as preliminary screening tools for language 
impairment. Gatt, O’Toole, \& Haman (2015) argue that measurements of vocabulary production can be one of the ways to identify early language delay.

Some efforts have already been made in this regard. O'Toole and Fletcher (2008) have adapted the CDI into a bilingual format, to assess bilingual Irish-English speakers. In their adaptation, the vocabulary items were listed in Irish, with an addition of two columns so parents could choose if the child produced the words either in Irish or English, or in both, by selecting both columns. A Maltese-English bilingual adaptation is also available (Gatt, 2007).

In a recent study from Gatt et al. (2015), the bilingual adaptations for IrishEnglish and Maltese-English were used to assess early lexical production, in order to establish a threshold for Specific Language Impairment in children that are exposed to more than one language. The study also employed adaptations of the CDIs that were not bilingual in form, but that were comprised of diverse language pairs: Polish-English, German-English, Hebrew-English, and French-Portuguese - using a different version of the CDI for European Portuguese (Frota, Butler, Correia, Severino, Vicente \& Vigário, 2015).

As suggested by Pearson (2013), because most of what is available are monolingual norms, researchers should use caution when using them. Or even better, develop novel ways to assess the many aspects of bilingual language acquisition, but especially lexical acquisition, as it has been done already for Maltese-English and IrishEnglish languages. 


\subsection{The present study}

The aim of the present study is to evaluate and compare the lexicons of bilingual and monolingual children. The study seeks to compare the vocabularies of monolingual English and monolingual Portuguese-speaking children with bilingual EnglishPortuguese-speaking children to compare the number of words and the nature of the words known. This study will make use of English and Portuguese Communicative Development Inventories (CDIs), to examine production and will consider both Conceptual and Total vocabulary scores. We predict, based on previous studies and relevant literature, that bilinguals might perform better than monolinguals when considering the Total vocabulary scores, but we expect no differences between bilinguals and monolinguals when comparing their Total Conceptual vocabularies. An examination of the acquisition of cognates and non-cognates in the bilinguals and monolinguals will be included to gauge the extent to which cognates are helpful for the bilingual group. It is hoped that this research will eventually lead to the development of a bilingual CDI with norms for assessment of Brazilian Portuguese-English bilingual children. 


\section{METHODOLOGY}

\subsection{Participants}

The data presented in this study are from parents of children between the ages of 16 to 36 months. The participants were divided into three groups according to the language(s) to which their children were exposed: only English, only Portuguese (monolingual groups) or both English and Portuguese (bilingual group). The total number of participants was 34 bilinguals, 14 English monolingual and 19 Portuguese monolingual. The mean age for the bilingual group was $M=24.4$ months (range 16 to 36 months); for the monolingual English group the mean age was $M=24.5$ months (range 19 to 35 months, and for the monolingual Portuguese group, the mean age was $M=26.8$ months (range 18 to 34 months).

The participants were recruited via social media (Facebook, Instagram), through advertisements in local newspapers dedicated to the Brazilian immigrants living in the United States, and via personal contacts and connections of the researcher. The monolingual English speakers were from the United States; the monolingual Portuguese speakers were from Brazil, (2 monolingual Portuguese speakers lived in the United States but had little or no exposure to English, as reported by their parents); and the bilingual participants were mostly from the United States ( 5 participants were from Brazil, 3 from Canada, 1 from England). There were both simultaneous and sequential children in the bilingual group, according to the parents, who were able to report when their children had first contact to the languages by answering the background questionnaire. 
If the parent reported that the child was exposed to another language other than Portuguese or English and that language was the dominant language, if the child had some type of speech delay, or if the child was younger than 16 months or older than 36 months, those children's responses were automatically excluded from the results. Prior to answering the questionnaires, the parents of the bilingual children were asked if they knew both English and Portuguese in order to be able to answer the questionnaires. If one parent did not speak one of the languages, the other parent was responsible for answering the questionnaire in the language that the first parent did not speak. If the parent reported that a child was exposed to a language other than Portuguese or English, but the exposure was minimal or limited, they were still included in the analysis, but this was noted for later analyses.

\subsection{Instruments}

For this study, the MacArthur Bates Communicative Development Inventories CDIs Words and Sentences (Fenson et al., 1993) and an adaptation of the the CDIPalavras e Frases (Words and Sentences) to Brazilian Portuguese (Teixeira, 2005) were adapted to be used electronically. In order to create electronic versions of the CDIs, both the English and the Portuguese versions of the inventories were entered into the survey platform Qualtrics. The Qualtrics survey software is widely used to create online surveys or any type of online data collection.

The English version of the CDI was entered in its entirety into Qualtrics (no modifications of any type, but in formatting), while the Brazilian-Portuguese version was entered into Qualtrics with some revisions (some words were added for the same item or 
modified according to this researcher's judgment in order to make the inventory more suitable for participants of all the regions of Brazil). These versions of the CDIs - Words and Sentences and Palavras e Frases - were answered respectively by monolingual English and monolingual Portuguese speakers.

For the bilingual groups, two versions were created, both comprising the entire version of the two inventories; however, one contained the English lists of words first, followed by the lists of words in Portuguese, and the other containing the Portuguese words first, followed by the English lists, as a counterbalance measure. All the participants were also asked to answer a background questionnaire containing important questions pertaining the study, such as language upbringing, language exposure, etc. (See Appendices 1 and 2). The answers from the background questionnaire allow for the application of the exclusionary criteria and analyses related to relative exposure to the languages.

The CDI - Words and Sentences is divided in two parts: Part 1: Words children use, and Part 2: Sentences and grammar. For this study, we only analyzed Part 1, which contains 680 words divided into 22 categories, as follows: 1 . Sound effects and animal sounds; 2. Animals (Real or Toy); 3. Vehicles (Real or Toy); 4. Toys; 5. Food and Drink; 6. Clothing; 7. Body parts; 8 . Small household items; 9. Furniture and rooms; 10 . Outside things; 11. Places to go; 12. People; 13. Games and routines; 14. Actions words; 15. Descriptive words; 16. Words about time; 17. Pronouns; 18. Question words; 19. Prepositions and locations; 20. Quantifiers and articles; 21. Helping verbs; and 22. Connecting Words. 
The Portuguese version of the CDI - Palavras e Frases mirrors the English version with two parts: Part 1 - O uso das palavras (Use of words) and Part 2: Orações e Gramática (Sentences and Grammar). Part 1, however, includes 23 categories, some identical to the English version, some not. The categories are as follows: 1. Sons de coisas e animais (Sounds of things and animals); 2. Animais - reais ou de brinquedo (Animals - real or toys); 3. Veículos - reais ou de brinquedo (Vehicles - real or toys); 4. Brinquedos (toys); 5. Roupas e acessórios (Clothes and accessories); 6. Corpo (Body); 7. Comidas e bebidas (Food and drinks); 8. Lugares fora da casa (Places outside the house); 9. Objetos externos (Outside objects); 10. Móveis e aposentos (Furniture and rooms); 11. Utensílios da casa (Home appliances/items); 12. Rotina diária e fórmulas sociais (Daily routine and social formulas); 13. Pessoas (People); 14. Palavras relacionadas ao tempo (Words related to time); 15. Quantificadores e locativos (Quantifiers and locatives); 16. Palavras de ação (Action words); 17. Verbos auxiliares (Auxiliary verbs); 18. Qualidades e atributos (Qualities and characteristics); 19. Perguntas (Questions); 20. Artigos (Articles); 21. Preposições (Prepositions); 22. Pronomes (Pronouns); and 23. Conectores (Conjunctions). The total number of words in the Portuguese version is 599.

The inventories can be examined following the links below:

Monolingual English: https://fiu.qualtrics.com/SE/?SID=SV 8kQAPb9qMALG5WB Monolingual Portuguese: https://fiu.qualtrics.com/SE/?SID=SV d6DClHO0cTU2jLD Bilingual English-first/Portuguese: https://fiu.qualtrics.com/SE/?SID=SV 40dJz1k3bobRDqR Bilingual Portuguese-first/English: https://fiu.qualtrics.com/SE/?SID=SV acagHsf5pHjrylf 
A comparison of the two CDIs yielded the following crosslinguistic groupings for the analyses of the bilinguals:

\section{Translation Equivalents:}

The words from the English and from the Portuguese versions of the CDIs were matched in order to find the Translation Equivalents (TEs). Of the vocabulary items on the two tests, 391 were TEs. The TEs were then examined for the occurrence of crosslanguage cognates (e.g., elefante (Portuguese) - elephant (English), [elefãt $[\mathrm{i}]$ - [Eləfənt]). In order to determine which words were cognates, the following principles were followed:

(1) The words had to have the same meaning or reference.

(2) The words must primarily share the same/corresponding consonants. We established that if two words shared all consonants or all consonants but one (except if this only left one shared consonant -- e.g., 'new' [nu] and 'novo' [novu]), they were included. For example, trator [trator] and tractor [træktər]. In making judgments on "shared" consonants, the following correspondences were allowed:

(a) Portuguese dentals and English alveolars were considered as corresponding consonants; for example: dançar [dãnsar] and dance [dæns]

(b) Portuguese $/ 3 /$ and the English $/ \widehat{\mathrm{d} z} /$ were considered equivalents; for example: pijamas [pizãmas] and pajamas [pədzæməz]

(c) the Portuguese sounds for ' $r$ ' ([r, $x]$ depending on the dialect) corresponded to English retroflex /x/; for example: carro [kaxu] and car $[\mathrm{kar}]$

and 
(d) The nasal vowels in Portuguese correspond to a vowel + a nasal in English. For example, planta [plãnta] and plant [plænt].

(3) The words should have a similar syllable structure in relation to the consonant-vowel pattern. E.g., the words café [kafe] and coffee [kofi] were treated as cognates, but the words star [sta. $]$ and estrela [estrela] were not.

The vowels can vary quite a bit across the two languages; there are some regular correspondences, but because of English vowel reduction, these can be unpredictable, so we did not take vowel quality into consideration.

Following these rules, the TEs were divided into two main categories: Translation Equivalents - Cognates (or just 'Cognates') (Appendix 3) and non-problematic noncognates Translation Equivalents (Appendix 4). Any words that were not clearly one category or the other (e.g., tigre [Jigre] and tiger [taigər] were classified as Translation Equivalents - Uncertain (Appendix 5), i.e., words that were not necessarily non-cognates, but that also didn't fit the Cognates category. The words that did not belong in either the Translation Equivalents lists are shown in Appendix 7, which shows the Non-Translation Equivalents on the Portuguese CDI, with their English meanings, and in Appendix 8, which shows the Non-Translation Equivalents in the English CDI, with their Portuguese meanings.

\section{Conceptual Vocabulary}

A second classification was made with regard to Conceptual Vocabulary.

Following Pearson (1998), the Total Conceptual Vocabulary is the number of concepts a child knows. For a monolingual, each word a child produces corresponds to a concept. For bilinguals, however, that is not the case, because a bilingual will express some 
concepts in only one of his/her languages, and some equivalent concepts in both of his/her languages. For example, a monolingual who has the words table and apple is credited with knowing the two concepts: the concept of what a table is and the concept of what an apple is, so the Total Conceptual vocabulary of a monolingual is the same as his/her Total Vocabulary.

The case with a bilingual child is more complex. For a bilingual child who knows the words table and apple but also knows the words mesa and maçã ('table' and 'apple' in Portuguese, respectively), we can say that this child has two concepts expressed through Translation Equivalents. When counting the Total Vocabulary of a bilingual, all the words in both of the bilinguals' languages are counted (so in the example above, the bilingual child would have a TV=4). In counting the Total Conceptual Vocabulary, this same child is credited with two concepts, TCV $=2$. (The Total Conceptual Vocabulary is the result of the difference between the Total Vocabulary minus the number of Translation Equivalent pairs).

However, this calculation of Conceptual Vocabulary is not always straightforward because languages behave differently. In many cases, there is a one-to-one correspondence between the TEs in the two languages -- i.e., one word in one language corresponds to only one word in the other, as exemplified by the pairs 'table-mesa' and 'apple-maçã' for English and Portuguese. These cases are clear and non-problematic. Sometimes, however, there is a one-to-many correspondence between the two languages. For example, the words finger and toe on the English CDI correspond to the entry dedo on the Portuguese CDI. How one counts the concepts involved is the issue? If a bilingual child has only the words finger and dedo in her lexicon, we could say that she has a TE 
pair 'finger-dedo', meaning that although she produces two words, she has one conceptIf another child has all three words -- finger, toe, and dedo, are these one or two concepts? The question becomes more problematic when one considers the meanings (i.e., concepts associated with these words) of these words: The words toe and finger are not essentially the same concept, since one is part of the foot and the other is part of the hand, whereas dedo means, more accurately, something like "digit".

On consultation with Pearson, Gatt, O'Toole, and Hickey (personal correspondence), we established a different way of counting conceptual vocabulary scores, as follows:

\section{Modified Total Vocabulary}

First, we established a "Modified Total Vocabulary" that excluded such cases. To come up with a Modified Total Vocabulary for bilinguals and for monolinguals, we excluded from the calculations of Total Vocabulary any words that had more than one correspondence in the other language. The excluded items are listed in Appendix 6. The Total Modified Vocabulary score is the Total Vocabulary score minus the 'problematic' words, calculated for both the monolinguals and for bilinguals.

\section{Conceptual Vocabulary}

Based on this Modified Vocabulary score, Total Conceptual Vocabulary scores were calculated. For the monolinguals, the TCV was equivalent to the modified vocabulary score; for the bilinguals, the TCV was equal to the Total Modified 
Vocabulary score minus the Translation Equivalents from the modified vocabulary list for which the child had the words in both languages. ${ }^{2}$

\subsection{Procedure}

After potential participants were contacted via social media or in person, or responded to the advertisement and contacted this researcher via email or phone, an email was sent to the participants. The email contained the 'Consent to Participate' link, in which an explanation of the research and its purpose were provided, as well as a description of the rights of the participants. The participants were asked to follow the link, read its contents, and then click on the 'Agree to Participate' button in the case they chose to do so. The email also contained a link with the research itself. Parents of monolingual English children answered the English electronic version of the CDI Words and Sentences and parents of monolingual Portuguese children answered the Portuguese electronic version of the CDI - Palavras e Frases. Parents of PortugueseEnglish bilingual children answered one of two versions of the inventories: English first, then Portuguese, or Portuguese first, then English. All participants were informed that the completion of the inventories and the background questionnaires would take between 25

\footnotetext{
${ }^{2}$ This is the procedure that is commonly followed in the literature. However, one issue needs to eventually be addressed. That is, this procedure might credit the bilingual child for concepts that are not tested in the "target" CDI. For example, the Portuguese CDI has the word aranha 'spider,' but the English CDI does not list the word spider. If we include this word in the bilingual child's conceptual vocabulary when her conceptual vocabulary is compared with the conceptual vocabulary of an English-speaking monolingual child, the comparison is problematic. It would credit the bilingual child with a concept that the monolingual English-speaking child doesn't show simply because the CDI for the monolingual child did not include that item. So we do not even know if the monolingual child has an equivalent concept. We do not address this issue further here, but believe it is worthy of careful consideration.
} 
to 35 minutes in case of monolinguals, and between 30 to 45 minutes, in case of bilinguals. The background questionnaires were provided in the respective languages for the monolingual participants, and in Portuguese for the bilinguals; however, the bilingual participants had the option to ask for the English version if they preferred to answer that form.

Only participants who received an email with the links to the inventories were able to participate in this study. In the beginning of the survey, the parents had to provide the date they were completing the inventories and the date of birth of their children, as well as the child's name. For the completion of the inventories, the parents were instructed to choose the words their children produce by clicking on each word. The word(s) chosen would turn 'red', so the parents would know the options they chose. They could 'unclick' a word if they made a mistake and also go back to a question. However, once they clicked the button 'Submit', they could not change their answers unless they contacted this researcher to request a manual modification of the answer. This did not occur, however.

The exclusion of participants, as mentioned above, only occurred when the parents reported that they were worried their child had some kind of language delay or if the child was undergoing speech therapy; if the child was exposed to a language other than Portuguese or English; or if the child did not belong to the age range between 16 and 36 months of age. After applying these criteria, 9 participants were excluded. The questions that allowed the exclusionary criteria mentioned above were part of the background questionnaire. 


\section{RESULTS}

This chapter will present the findings of this study. First, we compared the performance of the monolinguals and the bilinguals. In order to compare monolinguals and bilinguals alike, we used three different scores: Total Vocabulary of monolinguals compared to the Total Vocabulary of the bilinguals in each of the bilinguals' languages; Total Vocabulary of monolinguals compared to the Total Vocabulary of bilinguals in both languages, and Total Conceptual Vocabulary of bilinguals to the Total Conceptual Vocabulary of monolinguals. A separate set of analyses examine the performance of the bilinguals only, in order to determine the effect of cognates on performance. For the analysis Cognates were compared to Non-cognate Translation equivalents.

\subsection{Bilingual vs Monolingual}

\subsubsection{Portuguese}

Total vocabulary:

First, we examined the Total Vocabulary of monolinguals in comparison to the Total Portuguese Vocabulary portion of the bilinguals. We entered Language Group as the 'between subjects' factor, and Total Portuguese Vocabulary as the 'dependent' factor. We also entered Age (months) as a covariate. Results showed significant main effects of Language Group, where $F(1,50)=6.2, p=0.016$; and Age (months), where $F(1,50)=$ 49.6, $p<0.001$. The main effect of Language Group was due to the fact that the monolinguals had many more Portuguese vocabulary items $(M=318.7 ; \mathrm{SD}=27.8)$ than the bilinguals $(M=231.5 ; \mathrm{SD}=20.7)$. The significant effect of Age indicates that as children grew older, their vocabularies increased. 
Second, we compared the Total Vocabulary of Bilinguals (Total Portuguese Vocabulary + Total English Vocabulary) in both languages to the Total Vocabulary of monolingual Portuguese children. Although the results for bilinguals were slightly higher $(\mathrm{M}=372, \mathrm{SD}=26.65)$ than for the monolinguals $(\mathrm{M}=304, \mathrm{SD}=35.9)$, there was not a significant difference $F(1,50)=2.27, p=0.137$. Age (months), as anticipated, still appeared as significant: $F(1,50)=61.5, p<0.001$.

Figure 1 shows a comparison between the Total Vocabulary of Monolinguals and Bilinguals, both for Portuguese and English (to be discussed below).

Figure 1: Comparison of the Total Vocabulary of Bilinguals and Monolinguals. Means for Bilinguals: Bil Port $\mathrm{M}=231.5$; Bil Eng $\mathrm{M}=143$; Monolingual Portuguese $\mathrm{M}=318.7$; Monolingual English $\mathrm{M}=358$. 
Conceptual Vocabulary:

In order to compute the conceptual vocabulary, we first developed a "Modified Total Score," for the reasons outlined above. From this, the conceptual vocabulary score of the bilingual children was computed and compared with the totals for the monolinguals based on these modified totals.

The Total Conceptual Vocabulary (dependent variable) of bilinguals was compared to the Total Conceptual Vocabulary (based on the Total Modified Vocabulary) of monolingual Portuguese speakers. In this case, Language Group was not significant: $F$ $(1,50)=0.314, p=0.578$, with $\mathrm{M}=269, \mathrm{SD}=20.1$ for bilinguals, and $\mathrm{M}=288.2, \mathrm{SD}=27.07$ for monolinguals. Age (months) was still significant: $F(1,50)=53.28, p<0.001$, as expected, because as children get older, they learn more vocabulary concepts.

Figure 2 shows a comparison of the Total Conceptual Vocabulary of monolinguals and bilinguals. (Both Portuguese and English scores (to be discussed below) are shown). 


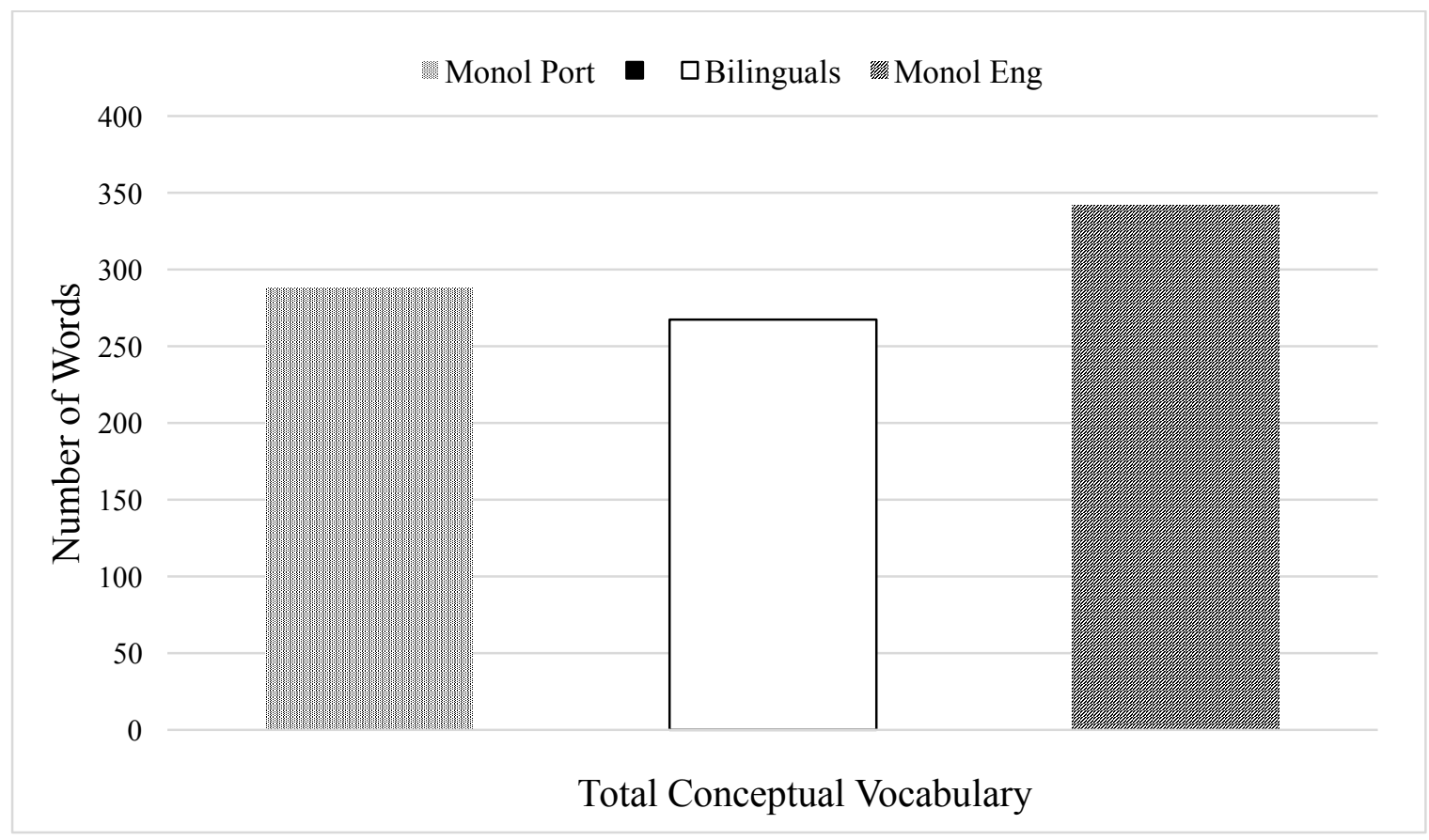

Figure 2: Comparison of Total Conceptual Vocabulary of Bilinguals and Monolinguals. The Mean for the bilinguals is $M=267.5$; Monolingual Portuguese $\mathrm{M}=288.2$; Monolingual English $\mathrm{M}=342$.

\subsubsection{English}

The same type of analyses were done with the monolingual English scores.

Total Vocabulary:

We compared the Total Vocabulary of monolingual English speakers to the Total English Vocabulary portion of the bilinguals. The Total English Vocabulary was entered as the dependent variable, with Age as covariate. Language Group had a significant main effect, with $F(1,45)=22.12, p<0.001$, and Age (months), with $F(1,45)=15.28, p<$ 0.001. The means for each group were $\mathrm{M}=143 ; \mathrm{SD}=24.3$ (bilinguals) and $\mathrm{M}=358$; $\mathrm{SD}=38.2$ (monolingual English), with the monolinguals showing more English words than the bilinguals have. 
Second, the Total Vocabulary of bilinguals in both languages was compared to the Total Vocabulary of monolingual English children. The means were $\mathrm{M}=326$, $\mathrm{SD}=47.1$ for monolinguals, and $\mathrm{M}=368, \mathrm{SD}=30$ for bilinguals. No main effects were found for Language Group $F(1,45)=0.561, p=0.458$. Age was significant, $F(1,45)=$ 52.28, $p<0.001$. (See Figure 1)

Conceptual Vocabulary:

The Total Conceptual Vocabulary (dependent variable) of the bilinguals was compared to the Conceptual Vocabulary scores of the monolinguals, as computed above, based on the Total Modified Vocabulary of monolingual English speakers. Language Group was not significant: $F(1,45)=2.561, p=0.117$. Age was again significant, $F(1$, $45)=37.9, p<0.001$. The means were $\mathrm{M}=266, \mathrm{SD}=25.15$ for the bilinguals, and $\mathrm{M}=342$, $\mathrm{SD}=39.51$ for monolinguals. (See Figure 2).

\subsection{Bilinguals only}

In order to determine whether cognates played a role in the acquisition of the lexical items, TEs that were cognates were compared with TEs that were non-cognates. We compared the proportions of the number of Cognates and the proportion of noncognates TEs the children knew (number of cognates present in the child's lexicon/total number of cognates possible in the "cognates" list (total $=50$ ); number of non-cognate TEs present in the child's lexicon/total number of non-cognate TEs in the "TE noncognates" list $($ total $=337)$.

A $t$-test comparing the two sets of scores was computed. There was a significant difference in performance on the cognates vs the non-cognates, $t(33)=10.657, p<.001$. 
There was a higher proportion of cognate TEs in the children's speech than of noncognates TEs: Translation Equivalents Non-cognates: $\mathrm{M}=0.1571, \mathrm{SD}=0.195$; Translation Equivalents - Cognates: $\mathrm{M}=0.2902, \mathrm{SD}=0.165$. 


\section{DISCUSSION}

In this chapter, the results of the analyses done for this study, as stated in Chapter 4, will be discussed in order to answer the research questions proposed in Chapter 1.

The first set of questions stated was: Will bilingual Portuguese-English-speaking children have similar patterns to those of other populations of bilingual children? Do they have translation pairs (Translation Equivalents) or do they avoid translation pairs? What proportion of their words are Translation Equivalents?

As per the results shown in Chapter 4, bilinguals produce fewer words in each of their languages when compared to monolinguals. The comparison of the Total Vocabulary of monolinguals to the Total Vocabulary of each language of the bilinguals showed that the bilinguals have fewer words in English, when compared to the monolingual English speakers and also fewer words in Portuguese, when compared to the monolingual Portuguese speakers. As per our predictions, this corresponds to similar findings in previous studies, and supports researchers' recommendation that bilinguals should be tested in their two languages (Patterson \& Pearson, 2004), not only one, otherwise it may appear that the bilinguals are deficient when compared to monolinguals.

However, the other two analyses conducted, when the Total Vocabulary and the Total Conceptual Vocabulary were compared and analyzed, for bilinguals in comparison to monolinguals showed that there is no significant difference between the two groups. On both measures, the bilinguals and the monolinguals scored similarly, confirming the predictions that these groups have similar vocabulary sizes when both of the languages of the bilinguals are taken into consideration during the analysis. 
The second part of the question inquires if the bilinguals have translation pairs Translation Equivalents - and if so, what is the proportion? The bilinguals do have TEs in their lexicons, however, the number of TEs is considerably low: Of the possible TEs, the children averaged $23.2 \%(2.1 \mathrm{SD})$ use of both of the words in the two languages. This might be explained by the distributed characteristics factor, one that says that the words bilinguals know are distributed across their two languages. The only factor that was consistently significant in the results was the Age of the children. As expected, as children get older, they learn more words, and with more words in their lexicons, the higher the number of TEs is expected to be.

The next research question was: do bilingual children perform better with the cognates as opposed to non-cognate TEs? How much does form-similarity matter for children's performance on words? From our results, it appears that cognate words help bilingual children acquire new vocabulary. Of the possible cognates, the children had $29 \%$ in both languages. And of the possible non-cognate translation equivalents, the children had $15 \%$ of the words in both languages.

The form-similarity of items seems to facilitate the acquisition of new words. I.e., a child who already knows, e.g., the word giraffe will be more likely to know the word girafa ('giraffe' in Portuguese) than if the two words were non-cognates.

The third question asked what would be the best way to incorporate the fact that these children are bilingual in their assessments? In first place, one of the most important points is to test bilinguals in both of their languages. As shown in the results above, if bilinguals are tested in only one of their languages, then they will probably be unfairly considered at a disadvantage in comparison to monolinguals. The development of a 
bilingual CDI that considers the characteristics of both languages of the bilinguals, and the effect of cognates and TEs in acquisition of vocabulary would be a step further in this field of study. There have been two bilingual CDIs developed so far: Irish-English and Maltese-English, and those are good examples to be followed.

Although the focus of this study was to answer the research questions mentioned above, some other issues surfaced during the development of this study that might require further and deeper analyses in the future. One of the issues was the decision of what words were cognates and what words were not. Even though we created rules to be able to assess if a word was a cognate and also to be consistent in this classification, within the category 'Cognates' there are different types of cognates. For example, the word pizza which was present in the two CDIs, pronounced very similarly in Portuguese and English, was considered a cognate. The words orange and laranja were also placed in the Cognates category, as it obeyed the rules created to classify words into cognates and noncognates. However, the words orange and laranja are not as clear in terms of being a cognate as the word pizza. This is an issue to be considered in future analyses involving cognates, in the sense that the type of cognates we consider (clear cognate vs non-clearcognate) might affect the results for that specific analysis.

Another issue is the fact that there are more Cognates between English and Portuguese than we were able to report for this study: the word mosquito is not present in the English CDI, however it is present in the Portuguese CDI ('mosquito', same spelling as English) and it is a clear cognate. The CDIs are not intended to be an exhaustive list, but if we had a more comprehensive list, maybe we could have a more accurate list of 
cognates as well, and therefore more accurate scores, as we could be more specific with the classification of Cognates.

As stated above, the CDI are not exhaustive lists. There are still a number of words that are 'missing' from the lists, even though they are commonly used by children aged 16-36 months. Some examples that might be included in the future are the names of shapes (square, triangle, circle, etc.) that are commonly taught and used by daycare teachers, appear in many children's books, and TV shows designed for the ages aforementioned. Other examples are the numbers: it is common practice for parents and educators, and educational TV shows to try and teach numbers to children. The Portuguese version of the CDI collapses some terms that were distinct into one category. For example: desenhar/pintar (draw/paint) belong to one item in the category 'Action words' but are two distinct actions. The words draw and paint in English appear each in one item so the parent has the option to choose one, two, or neither depending whether the child says the words or not. The Portuguese-speaking child may know both words, but she will be credited with only 1 'point', because there are not two items from which the parent has to choose. This situation is present in many other examples: tio/tia (uncle/aunt), menino/menina (boy/girl) are also presented as one item in the category 'Pessoas' (People) in the Portuguese CDI, whereas the words uncle and aunt, and boy and girl appear as separate items in the English CDI. Such cases make the comparison of the two languages of bilingual children difficult. As the Portuguese CDI is not yet normed, one suggestion would be to separate those words, put them as individual items, so the parents have a clearer set of options while answering the inventories. 
Another issue we found after reviewing the CDIs was the fact that there were words that were repeated in different categories. For example, the word water appears in the category 'Food and drinks' and then again in the category 'Outside things' for the English CDI. In this case, the same word is counted twice if the parent marks both items, or it might be counted only once, if the parent only chooses one category. That may create a different type of issue: when a child says the word water inside the house is she referring to the water we drink and only that? When a child says the word water when she sees a lake outside, or even the ocean, is there a different 'type' of water than the water we drink? Are those two separate concepts in the child's mind or only one? This is further complicated in the case of the bilingual child, since água is only listed in one of the categories, "Comidas e bebidas" (Food and drinks). The same case happens for the word planta (plant) in Portuguese, which appears in two different categories: 'Objetos externos' (Outside things) and 'Utensílios da casa' (Small household items) (and in only one place in English - 'Small household items'). If the parents choose the word planta from the two categories, then the word will be counted twice in Portuguese, even though it may be only one concept. When these issues are taken into consideration, such items may profit from revising and re-configuring the lists, to enable more reliable results.

One a positive note, the fact that we used the internet to collect the data for this study was a good factor, as it facilitated the process immensely. We were able to have access to people from all over the world (although our participants were from specific regions where the languages cited in this study were spoken). There was no need to pick up report forms from parents or have them delivered via mail. Everything could be done via the internet. (This procedure still shares issues with the non-electronic CDIs in that 
one is relying on the parent for all the information given and has no access to the child whatsoever.) This is a methodology that has been useful and efficient and should be used in the future more often, as more people have access to the internet and to computers.

\subsection{Limitations of this study}

One of the main limitations encountered during this project was the fact that our sample size was not a balanced sample. We had 34 bilingual participants to compare to 14 monolingual English and 19 monolingual Portuguese. Ideally, a higher number of participants would be better as it would allow for a more accurate final result. It would also have been more interesting to have more detailed information on what type of exposure the bilinguals have in each of their languages. A more meticulous analysis considering the children's age, age of acquisition of their languages, and socio-economic status would also be appropriate, and these analyses will be conducted on these and more data in the future. 


\section{REFERENCES}

Almgrem, M., Ezeizabarrena, M.J. \& Garcia, I. (2007). The Basque CDI: Applications in a bilingual society. In M. Eriksson (Ed.) Proceedings from the First European Network Meeting on the Communicative Development Inventories (pp. 83-92). Gävle: Gävle University Press. ISBN: 978-91-974948-8-5

Berglund, E. \& Eriksson, M. (1996). Different sampling methods of parental reports. The case for the Swedish Early Communicative Development Inventory, SECDI. Poster presented at the VIIth International Congress for the Study of Child Language, 14-19 July, Istanbul, Turkey.

Bialystok, E. (2001). Bilingualism in development: Language, literacy, and cognition. Cambridge, England: Cambridge University Press.

Bornstein, M. H., \& Haynes, O. M. (1998). Vocabulary Competence in Early Childhood: Measurement, Latent Construct, and Predictive Validity. Child Development, 69(3), 654-671. http://doi.org/10.2307/1132196

Bosch, L., \& Ramon-Casas, M. (2014). First translation equivalents in bilingual toddlers' expressive vocabulary: Does form similarity matter? International Journal of Behavioral Development, 38 (4) 317-322. http://dx.doi.org/10.1177/0165025414532559

Cartmill, E.A., Armstrong III, B.F., Gleitman, L. R., Goldin-Meadow, S., Medina, T.N., \& Trueswell, J.C. (2013). Quality of early parent input predicts child vocabulary 3 years later. Proceedings of the National Academy of Sciences of the United States of America. doi: 10.1073/pnas.1309518110

Caselli, M. C. \& Casadio, P. (1995). Il primo vocabolario del bambino: guida all'uso del questionario MacArthur. Milan, Italy: Franco Angeli.

Core, C., Hoff, E., Rumiche, R., \& Señor, M. (2013). Total and Conceptual Vocabulary in Spanish-English Bilinguals From 22 to 30 Months: Implications for Assessment. Journal of Speech, Language, and Hearing Research: JSLHR, 56(5), 1637-1649. http://doi.org/10.1044/1092-4388(2013/11-0044)

Dale, P. S. \& Penfold, M. (2011). Adaptations of the MacArthur-Bates CDI into non-U.S. English languages. Retrieved from http://mbcdi.stanford.edu/documents/AdaptationsSurvey7-5-11Web.pdf

De Houwer, A. (2005). Bilingualism: an interview with Annick De Houwer. ReVEL. Vol. 3, n. 5, 2005. ISSN 1678-8931 [www.revel.inf.br/eng].

De Houwer, A. (2012). Milestones in bilingual children's language development. Encyclopedia of Language and Literacy Development (pp. 1-8). London, ON: 
Western University. Retrieved from http://literacyencyclopedia.ca/pdfs/topic.php?topId=313

De Houwer, A., Bornstein, M. H., and Putnick, D. L. (2014). A bilingual-monolingual comparison of young children's vocabulary size: Evidence from comprehension and production. Applied Psycholinguistics, 35, pp 1189-1211. doi:10.1017/S0142716412000744.

Dijkstra, T., Miwa, K., Brummelhuis, B. Sappelli, M., Baayen, H. (2010). How crosslanguage similarity and task demands affect cognate recognition. Journal of Memory and Language. 62, 284-301.

Feldman, H. M., Dollaghan, C. A., Campbell, T. F., Kurs-Lasky, M., Janosky, J. E., \& Paradise, J. L. (2000). Measurement Properties of the MacArthur Communicative Development Inventories at Ages One and Two Years. Child Development, 71(2), 310-322. Retrieved from http://www.jstor.org/stable/1131991

Fenson, L., Dale, P. S., Reznick, J.S., Thal, D., Bates, E., Hartung, J. P., Pethick, S. J. \& Reilly, J. S. (1993). The MacArthur Communicative Development Inventories. San Diego, CA: Singular.

Fenson, L., Dale, P., Reznick, J., Bates, E., Thal, D., \& Pethick, S. (1994). Variability in early communicative development. Monographs of the Society for Research in Child Development, Serial No. 242, Vol. 59, No. 5.

Fenson, L., Bates, E., Dale, P., Goodman, J., Reznick, J. S., \& Thal, D. (2000). Measuring Variability in Early Child Language: Don't Shoot the Messenger: [Reply]. Child Development, 71(2), 323-328. Retrieved from http://www.jstor.org/stable/1131992

Fenson, L., Marchman, V.A., Thal, D.J., Dale, P.S., Reznick, J.S., \& Bates, E. (2007). MacArthur-Bates Communicative Development Inventories. User's guide and technical manual. Second Edition. Baltimore: Brookes Publishing.

Frota, S., J. Butler, S. Correia, C. Severino, S. Vicente \& M. Vigário. (2015). MacArthurBates Communicative Development Inventories (CDI) for European Portuguese: Short forms. Lisboa: Laboratório de Fonética, CLUL/FLUL. [http://labfon.letras.ulisboa.pt/babylab/pt/CDI]

Gândara, J. P., \& Befi-Lopes, D. M. (2010). Tendências da aquisição lexical em crianças em desenvolvimento normal e crianças com Alterações Específicas no Desenvolvimento da Linguagem. Revista da Sociedade Brasileira de Fonoaudiologia, 15(2), 297-304. https://dx.doi.org/10.1590/S151680342010000200024 
Gathercole, V. C. M. (2002). Command of the mass/count distinction in bilingual and monolingual children: An English morphosyntactic distinction. In D. K. Oller \& R. E. Eilers (eds.), Language and literacy in bilingual children. Clevedon: Multilingual Matters. 175-206.

Gathercole, V. C. M., \& Thomas, E. M. (2009). Bilingual first-language development: Dominant language take- over, threatened minority language take-up.

Bilingualism: Language \& Cognition, 12(2), 213-237. doi: 10.1017/S1366728909004015

Gathercole, V.C.M., Thomas, E.M., Roberts, E.J., Hughes, C.O., \& Hughes, E.K. (2013). Why assessment needs to take exposure into account: Vocabulary and grammatical abilities in bilingual children. In VCM Gathercole (ed.), Issues in the assessment of bilinguals. Bristol: Multilingual Matters. 20-55.

Gathercole, V. C. M. (2014). Bilingualism matters: One size does not fit all. Special Issue on "Language Development in Multilingual Environments," edited by Erika Hoff. International Journal of Behavioral Development, 38 (4), 359 - 366.

Gatt, D., O’Toole, C., \& Haman, E. (2015). Using parental report to assess early lexical production in children exposed to more than one language. In S. Armon- Lotem, J. De Jong, \& N. Meir (Eds) Assessing Multilingual Children Disentangling Bilingualism from Language Impairment, pp.151-195. Bristol: Multilingual Matters.

Gatt, D. (2007). Establishing the concurrent validity of a vocabulary checklist for young Maltese children. Folia Phoniatrica et Logopaedica, 59 (6), 297-305.

Genesee, F., \& Nicoladis, E. (2006). Bilingual acquisition. In E. Hoff \& M. Shatz (eds.), Handbook of Language Development, Oxford, Eng.: Blackwell.

Grosjean, F. (2013). Bilingualism: A Short Introduction. The Psycholinguistics of Bilingualism, First edition. Oxford: Wiley-Blackwell

Heilmann, J., Weismer, S.E., Evans, J., Hollar, C. (2005). Utility of the MacArthur-Bates Communicative Development Inventory in identifying language abilities of latetalking and typically developing toddlers. American Journal of Speech-Language Pathology, 14, 40-51.

Hoff, E. (2009). Language Development at an Early Age: Learning Mechanisms and Outcomes from Birth to Five Years. Language Development and Literacy. Encyclopedia on Early Childhood Development. 
Hoff, E., Core, C., Place, S., Rumiche, R., Señor, M., \& Parra, M. (2012). Dual language exposure and early bilingual development. Journal of Child Language 39, pp 127. doi: $10.1017 / \mathrm{S} 0305000910000759$

Jackson-Maldonado, D., Marchman, V., Thal, D., Bates, E., Gutiérrez-Clellen, V. (1993) Early lexical development in Spanish-speaking infants and toddlers. Journal of Child Language 20: 523-549

Kristoffersen, K. E., Simonsen, H. G., Bleses, D., Wehberg, S., Jørgensen, R. N., Eiesland, E. A. \& Henriksen, L. Y. (2012). The use of the Internet in collecting CDI data - an example from Norway. Journal of Child Language, 39(5).

Marchman, V.A. \& Martínez-Sussman, C. (2002). Concurrent validity of caregiver/parent report measures of language for children who are learning both English and Spanish. Journal of Speech, Language and Hearing Research, 45, 983-997.

Macrory, G. (2006) Bilingual language development: what do early years practitioners need to know?, Early Years, 26:2, 159-169, DOI: 10.1080/09575140600759955

O'Grady, W. D., Archibald, J., Aronoff, M., \& Rees-Miller, J. (2010). Contemporary linguistics: An introduction. New York: Bedford.

Oller, D. K. (2005). The distributed characteristic in bilingual learning. In J. Cohen, K. T. McAlister, K. Rolstad \& J. MacSwan (Eds.), ISB4: Proceedings of the $4^{\text {th }}$ International Symposium on Bilingualism (pp. 1744-1749). Somerville, MA: Cascadilla Press.

O'Toole, C. (2013) Using parent report to assess bilingual vocabulary acquisition: A model from Irish. In: Gathercole, VCM (eds). Solutions for the Assessment of Bilinguals. Bristol: Multilingual Matters.

O'Toole, C. and Fletcher, P. (2008). Developing assessment tools for bilingual and minority language acquisition. Journal of Clinical Speech and Language Studies. $16,12-27$

Patterson, J. \& Pearson, B. Z. (2004). Bilingual lexical development: Influences, contexts, and processes. In G. Goldstein, (Ed.) Bilingual Language Development and Disorders in Spanish-English Speakers (pp. 77-104). Baltimore, MD: Paul Brookes.

Pearson, B. Z. (2013). Distinguishing the bilingual as a late talker from the later talker who is bilingual. In L. Rescorla \& P. Dale (Eds.), Late talkers: Language development, interventions, and outcomes (pp. 67-87). Baltimore MD: Paul Brookes. 
Pearson, B. Z. (2009). Children with two languages. In E. Bavin (Ed.), Handbook of Child Language. Cambridge: Cambridge University Press.

Pearson, B. Z. (2008). Raising a bilingual child: A step-by-step guide for parents. NY: Random House.

Pearson, B. Z. (1998). Assessing lexical development in bilingual babies and toddlers. IJB 2, 347-372.

Pearson, B. Z., \& Fernandez, S. (1994). Patterns of interaction in the lexical development in two languages of bilingual infants. Language Learning, 44, 617-653.

Poulin-Dubois, D., Bialystok, E., Blaye, A., Polonia, A., \& Yott, J. (2013). Lexical access and vocabulary development in very young bilinguals. The International Journal of Bilingualism : Cross-Disciplinary, Cross-Linguistic Studies of Language Behavior, 17(1), 57-70. http://doi.org/10.1177/1367006911431198

Sebastian-Galles, N. (2010). Bilingual Language Acquisition: Where does the Difference Lie? Human Development; 53:245-255 Universitat Pompeu Fabra, Barcelona, Spain doi: 10.1159/000321282

Silva, C. T. S. da (2003) O desenvolvimento lexical inicial dos 8 aos 16 meses a partir do Inventário Macarthur de Desenvolvimento Comunicativo - protocolo Palavras e Gestos. Dissertação Inédita de Mestrado, UFBA.

Silva, C. T. S. da. (2006) Considerações em torno da adaptação do protocolo Palavras e Gestos do Inventário MacArthur de Desenvolvimento Comunicativo. Revista Inventário. 5. ed. Retrieved from: http://www.inventario.ufba.br/05/05csilva.htm.

Slobin, D (2006). Cross-Linguistic Comparative Approaches to Language Acquisition. In: Keith Brown, (Editor-in-Chief) Encyclopedia of Language \& Linguistics, Second Edition, 3, 299-301. Oxford: Elsevier.

Teixeira, E.R. (2005). CDI's Adaptation to Brazilian Portuguese: Validation Study of the Words and Sentences Form. X International Congress for the Study of Child Language. http://www.ctw- congress.de/iascl/download/iascl_abstracts.pdf, Berlin.

Thordardottir, E. (2005). Language intervention from a bilingual mindset. Perspectives on Language Learning and Education, 12 (2), 17-22. ASHA Leader

Words \& Sentences from Mac Arthur-Bates Communicative Development Inventories (CDIs), Second Edition, Fenson et al. (C) 2007 The CDI Advisory Board. Used by permission. www.brookespublishing.com $\backslash$ 


\section{APPENDICES}

\section{Appendix 1}

English Background Questionnaire

This is a questionnaire about your child's language upbringing. It should be completed by the child's main caregiver; i.e., the person who spends most time with the child.

Questionnaire adapted from work of Gathercole et al.

Gathercole, Virginia C. Mueller, Thomas, Enlli Môn, Jones, Leah, Viñas Guasch, Nestor, Young, Nia, \& Hughes, Emma K. (2010)

Stadthagen-González, Hans, Gathercole, Virginia C. Mueller, Pérez-Tattam, Rocío, \& Yavas, Feryal. (2013)

Gathercole, Virginia C. Mueller, Thomas, Enlli Môn, Roberts, Emily, Hughes, Catrin, \& Hughes, Emma K. (2013)

Pérez-Tattam, Rocío, Gathercole, Virginia C. Mueller, Yavas, Feryal, StadthagenGonzález, Hans, \& Anrrich, Graciela. (2013)

Q47 I would be very grateful if you could answer the following background information questionnaire. The information provided will help with this study. Please feel free to leave any item blank if you prefer not to answer.

Child's Name (1)

Child's Date of Birth (2)

Child's Place of Birth (3)

Q48 Birth order:

O 1st Born (Oldest) (1)

O 2nd Born (2)

3rd Born (3)

O 4th Born (4)

O 5th Born (5)

○ 6th Born (6)

Q49 Contact details of Parent:

Name: (1)

Email: (2)

Telephone: (3) 
Q50 Is your child?

O Male (1)

Female (2)

Q51 Was your child born in the United States of America?

Y Yes (1)

No (2)

Q52 If your child was not born in the USA:

At what age did s/he move to the USA? (1)

How long has she lived in the USA? (2)

N/A (3)

Q53 Please indicate the areas where your child has lived for significant periods (more than a year) of his/her life:

e.g.: $\quad$ Place and Date: São Paulo, Brazil; 2012-14

Place and Date: New York City, NY; 2014-15

Place and Date: Miami, FL; 2015

Place and Date: (1)

Place and Date: (2)

Place and Date: (3)

Q54 LANGUAGE UPBRINGING

Which of the following languages does your child speak? (Please, select all that apply)

$\square$ Portuguese (1)

$\square$ English (2)

$\square$ Other language (3)

Q55 If your child speaks Portuguese, when did s/he begin speaking it?

$O$ as a baby (1)

$O$ by age 1 (2)

$\mathrm{O}$ by age 2 (3)

O N/A (4)

Q56 If your child speaks English, when did s/he begin speaking it?

$\mathrm{O}$ as a baby (1)

$\bigcirc$ by age 1 (2)

$\mathrm{O}$ by age 2 (3)

O N/A (4) 
Q57 If your child speaks a language other than Portuguese or English:

What language? (1)

$\mathrm{S} /$ he began speaking this language at around age? (2)

Q58 What language(s) did the child's mother and/or father speak to him or her AT HOME from birth until today?

\begin{tabular}{|c|c|c|c|c|c|c|c|c|}
\hline & $\begin{array}{c}\text { Virtua } \\
\text { 1ly } \\
100 \% \\
\text { Englis } \\
\text { h (1) }\end{array}$ & $\begin{array}{c}\text { About } \\
80 \% \\
\text { English; } \\
20 \% \\
\text { Portugu } \\
\text { ese (2) }\end{array}$ & $\begin{array}{c}\text { About } \\
60 \% \\
\text { English; } \\
40 \% \\
\text { Portugu } \\
\text { ese (3) }\end{array}$ & $\begin{array}{c}\text { About } \\
50 \% \\
\text { English; } \\
50 \% \\
\text { Portugu } \\
\text { ese (4) }\end{array}$ & $\begin{array}{c}\text { About } \\
40 \% \\
\text { English; } \\
60 \% \\
\text { Portugu } \\
\text { ese (5) }\end{array}$ & $\begin{array}{c}\text { About } \\
20 \% \\
\text { English, } \\
80 \% \\
\text { Portugu } \\
\text { ese (6) }\end{array}$ & $\begin{array}{c}\text { Virtuall } \\
\text { y } 100 \% \\
\text { Portugu } \\
\text { ese ( } 7 \text { ) }\end{array}$ & $\begin{array}{l}\mathrm{N} / \\
\mathrm{A} \\
(8)\end{array}$ \\
\hline $\begin{array}{l}\text { Moth } \\
\text { er (1) }\end{array}$ & 0 & $\bigcirc$ & 0 & 0 & 0 & 0 & $\bigcirc$ & 0 \\
\hline $\begin{array}{c}\text { Fathe } \\
\text { r (2) }\end{array}$ & 0 & 0 & 0 & 0 & 0 & 0 & 0 & $\bigcirc$ \\
\hline
\end{tabular}

Q59 What language(s) did the child speak to his/her mother and/or father BEFORE s/he began day care or early childhood education?

\begin{tabular}{|c|c|c|c|c|c|c|c|c|}
\hline & $\begin{array}{c}\text { Virtua } \\
\text { lly } \\
100 \% \\
\text { Englis } \\
\text { h (1) }\end{array}$ & $\begin{array}{c}\text { About } \\
80 \% \\
\text { English; } \\
20 \% \\
\text { Portugu } \\
\text { ese (2) }\end{array}$ & $\begin{array}{c}\text { About } \\
60 \% \\
\text { English; } \\
40 \% \\
\text { Portugu } \\
\text { ese (3) }\end{array}$ & $\begin{array}{c}\text { About } \\
50 \% \\
\text { English; } \\
50 \% \\
\text { Portugu } \\
\text { ese (4) }\end{array}$ & $\begin{array}{c}\text { About } \\
40 \% \\
\text { English; } \\
60 \% \\
\text { Portugu } \\
\text { ese (5) }\end{array}$ & $\begin{array}{c}\text { About } \\
20 \% \\
\text { English, } \\
80 \% \\
\text { Portugu } \\
\text { ese (6) }\end{array}$ & $\begin{array}{c}\text { Virtuall } \\
\text { y } 100 \% \\
\text { Portugu } \\
\text { ese ( } 7)\end{array}$ & $\begin{array}{c}\mathrm{N} / \\
\mathrm{A} \\
(8)\end{array}$ \\
\hline $\begin{array}{l}\text { Moth } \\
\text { er (1) }\end{array}$ & 0 & 0 & 0 & 0 & 0 & 0 & 0 & 0 \\
\hline $\begin{array}{l}\text { Fathe } \\
\text { r (2) }\end{array}$ & 0 & 0 & 0 & 0 & 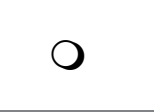 & 0 & 0 & $\bigcirc$ \\
\hline
\end{tabular}

Q60 What language(s) did the child speak to his/her mother and/or father AFTER s/he began day care or early childhood education?

\begin{tabular}{|c|c|c|c|c|c|c|c|c|}
\hline & $\begin{array}{l}\text { Virtua } \\
\text { 1ly } \\
100 \% \\
\text { Englis } \\
\text { h (1) }\end{array}$ & $\begin{array}{c}\text { About } \\
80 \% \\
\text { English; } \\
20 \% \\
\text { Portugu } \\
\text { ese (2) }\end{array}$ & $\begin{array}{c}\text { About } \\
60 \% \\
\text { English; } \\
40 \% \\
\text { Portugu } \\
\text { ese (3) }\end{array}$ & $\begin{array}{c}\text { About } \\
50 \% \\
\text { English; } \\
50 \% \\
\text { Portugu } \\
\text { ese (4) }\end{array}$ & $\begin{array}{c}\text { About } \\
40 \% \\
\text { English; } \\
60 \% \\
\text { Portugu } \\
\text { ese (5) }\end{array}$ & $\begin{array}{c}\text { About } \\
20 \% \\
\text { English, } \\
80 \% \\
\text { Portugu } \\
\text { ese (6) }\end{array}$ & $\begin{array}{c}\text { Virtuall } \\
\text { y } 100 \% \\
\text { Portugu } \\
\text { ese (7) }\end{array}$ & $\begin{array}{c}\mathrm{N} / \\
\mathrm{A} \\
\text { (8) }\end{array}$ \\
\hline $\begin{array}{l}\text { Moth } \\
\text { er (1) }\end{array}$ & 0 & 0 & 0 & 0 & 0 & 0 & 0 & 0 \\
\hline $\begin{array}{c}\text { Fathe } \\
\text { r (2) }\end{array}$ & 0 & 0 & 0 & 0 & 0 & 0 & 0 & 0 \\
\hline
\end{tabular}


Q61 What language(s) does the child's younger/older siblings speak to him/her (if applicable)?

\begin{tabular}{|c|c|c|c|c|c|c|c|c|}
\hline & $\begin{array}{c}\text { Virtua } \\
\text { 1ly } \\
100 \% \\
\text { Englis } \\
\text { h (1) }\end{array}$ & $\begin{array}{c}\text { About } \\
80 \% \\
\text { English; } \\
20 \% \\
\text { Portugu } \\
\text { ese (2) }\end{array}$ & $\begin{array}{c}\text { About } \\
60 \% \\
\text { English; } \\
20 \% \\
\text { Portugu } \\
\text { ese (3) }\end{array}$ & $\begin{array}{c}\text { About } \\
50 \% \\
\text { English; } \\
50 \% \\
\text { Portugu } \\
\text { ese (4) }\end{array}$ & $\begin{array}{c}\text { About } \\
40 \% \\
\text { English; } \\
60 \% \\
\text { Portugu } \\
\text { ese (5) }\end{array}$ & $\begin{array}{c}\text { About } \\
20 \% \\
\text { English, } \\
80 \% \\
\text { Portugu } \\
\text { ese (6) }\end{array}$ & $\begin{array}{c}\text { Virtuall } \\
\text { y } 100 \% \\
\text { Portugu } \\
\text { ese ( } 7 \text { ) }\end{array}$ & $\begin{array}{c}\mathrm{N} / \\
\mathrm{A} \\
(8)\end{array}$ \\
\hline $\begin{array}{l}\text { Young } \\
\text { er } \\
\text { Sibling } \\
\text { (s) to } \\
\text { the } \\
\text { child } \\
\text { (1) }\end{array}$ & 0 & 0 & 0 & 0 & 0 & 0 & 0 & O \\
\hline $\begin{array}{l}\text { Older } \\
\text { Sibling } \\
\text { (s) to } \\
\text { the } \\
\text { child } \\
\text { (2) }\end{array}$ & 0 & 0 & 0 & 0 & 0 & 0 & 0 & O \\
\hline
\end{tabular}

Q62 What language(s) does the child speak to younger/older sibling(s) (if applicable)?

\begin{tabular}{|c|c|c|c|c|c|c|c|c|}
\hline & $\begin{array}{c}\text { Virtua } \\
\text { 1ly } \\
100 \% \\
\text { Englis } \\
\text { h (1) }\end{array}$ & $\begin{array}{c}\text { About } \\
80 \% \\
\text { English; } \\
20 \% \\
\text { Portugu } \\
\text { ese (2) }\end{array}$ & $\begin{array}{c}\text { About } \\
60 \% \\
\text { English; } \\
40 \% \\
\text { Portugu } \\
\text { ese (3) }\end{array}$ & $\begin{array}{c}\text { About } \\
50 \% \\
\text { English; } \\
50 \% \\
\text { Portugu } \\
\text { ese (4) }\end{array}$ & $\begin{array}{c}\text { About } \\
40 \% \\
\text { English; } \\
60 \% \\
\text { Portugu } \\
\text { ese (5) }\end{array}$ & $\begin{array}{c}\text { About } \\
20 \% \\
\text { English, } \\
80 \% \\
\text { Portugu } \\
\text { ese (6) }\end{array}$ & $\begin{array}{c}\text { Virtuall } \\
\text { y } 100 \% \\
\text { Portugu } \\
\text { ese (7) }\end{array}$ & $\begin{array}{c}\mathrm{N} / \\
\mathrm{A} \\
(8)\end{array}$ \\
\hline $\begin{array}{l}\text { Child } \\
\text { to } \\
\text { Young } \\
\text { er } \\
\text { Sibling } \\
\text { (s) (1) }\end{array}$ & 0 & 0 & 0 & 0 & 0 & 0 & 0 & 0 \\
\hline $\begin{array}{l}\text { Child } \\
\text { to } \\
\text { Older } \\
\text { Sibling } \\
\text { (s) (2) }\end{array}$ & 0 & 0 & 0 & 0 & 0 & 0 & 0 & 0 \\
\hline
\end{tabular}


Q63 Are there any other significant adult(s) (grandparents, aunts, uncles, etc.) with whom the child has frequent contact?

O Yes (1)

No (2)

Q64 If yes, answer the following for each:

Q65 Adult 1 Please specify his/her relationship to you child:

Q66 Adult 1 What language(s) does this person speak to your child?

O Always English (1)

O Always Portuguese (2)

O Sometimes English, sometimes Portuguese (3)

O Other (4)

Q67 Adult 1 How often does your child see this person?

O Every day (1)

At least once a week (2)

O About once a month (3)

Once or twice a year (4)

O Less often (5)

Q68 Adult 2Please specify his/her relation to your child:

Q69 Adult 2What language(s) does this person speak to your child?

O Always English (1)

O Always Portuguese (2)

O Sometimes English, sometimes Portuguese (3)

O Other (4)

Q70 Adult 2How often does your child see this person?

O Every day (1)

At least once a week (2)

O About once a month (3)

Once or twice a year (4)

O Less often (5) 
Q71 With whom does the child spend most of his/her day?

O Mother (1)

Father (2)

Grandparents (3)

Babysitter (4)

Other (5)

Q72 Day care center

What is the normal language of instruction in the day care center your child attends (if relevant)?

\begin{tabular}{|c|c|c|c|c|c|c|c|c|}
\hline & $\begin{array}{c}\text { Virtual } \\
\text { ly } \\
100 \% \\
\text { Englis } \\
\text { h (1) }\end{array}$ & $\begin{array}{c}\text { About } \\
80 \% \\
\text { English; } \\
20 \% \\
\text { Portugu } \\
\text { ese (2) }\end{array}$ & $\begin{array}{c}\text { About } \\
60 \% \\
\text { English; } \\
40 \% \\
\text { Portugu } \\
\text { ese (3) }\end{array}$ & $\begin{array}{c}\text { About } \\
50 \% \\
\text { English; } \\
50 \% \\
\text { Portugu } \\
\text { ese (4) }\end{array}$ & $\begin{array}{c}\text { About } \\
40 \% \\
\text { English; } \\
60 \% \\
\text { Portugu } \\
\text { ese (5) }\end{array}$ & $\begin{array}{c}\text { About } \\
20 \% \\
\text { English, } \\
80 \% \\
\text { Portugu } \\
\text { ese (6) }\end{array}$ & $\begin{array}{c}\text { Virtuall } \\
\text { y } 100 \% \\
\text { Portugu } \\
\text { ese ( } 7)\end{array}$ & $\begin{array}{c}\mathrm{N} / \\
\mathrm{A} \\
(8)\end{array}$ \\
\hline $\begin{array}{l}\text { Day } \\
\text { care } \\
\text { cent } \\
\text { er } \\
\text { (1) }\end{array}$ & 0 & 0 & 0 & 0 & 0 & 0 & 0 & 0 \\
\hline
\end{tabular}

Q73 Day care center Other language combination? Please, specify:

Q74 Overall, what language(s) does your child speak with most of her/his friends?

\begin{tabular}{|c|c|c|c|c|c|c|c|c|}
\hline & $\begin{array}{c}\text { Virtual } \\
\text { ly } \\
100 \% \\
\text { Englis } \\
\text { h (1) }\end{array}$ & $\begin{array}{c}\text { About } \\
80 \% \\
\text { English; } \\
20 \% \\
\text { Portugu } \\
\text { ese (2) }\end{array}$ & $\begin{array}{c}\text { About } \\
60 \% \\
\text { English; } \\
40 \% \\
\text { Portugu } \\
\text { ese (3) }\end{array}$ & $\begin{array}{c}\text { About } \\
50 \% \\
\text { English; } \\
50 \% \\
\text { Portugu } \\
\text { ese (4) }\end{array}$ & $\begin{array}{c}\text { About } \\
40 \% \\
\text { English; } \\
60 \% \\
\text { Portugu } \\
\text { ese (5) }\end{array}$ & $\begin{array}{c}\text { About } \\
20 \% \\
\text { English, } \\
80 \% \\
\text { Portugu } \\
\text { ese (6) }\end{array}$ & $\begin{array}{c}\text { Virtuall } \\
\text { y } 100 \% \\
\text { Portugu } \\
\text { ese ( } 7 \text { ) }\end{array}$ & $\begin{array}{c}\mathrm{N} / \\
\mathrm{A} \\
(8)\end{array}$ \\
\hline $\begin{array}{l}\text { Chil } \\
\mathrm{d} \text { to } \\
\text { frien } \\
\mathrm{ds} \\
(1)\end{array}$ & 0 & 0 & 0 & 0 & 0 & $\bigcirc$ & $\bigcirc$ & 0 \\
\hline
\end{tabular}

Q75 With friends

Other language combination? Please, specify: 
Q76 GENERAL INFORMATION Please, indicate the level of education completed by the child's MOTHER:

O Primary education (Grade School) (1)

Secondary education (High School) (2)

University or college education (3)

Post-graduate education (4)

None of the above (5)

Q77 Please, indicate in which country or region was the mother born?

Q78 What is the child's mother's occupation (or if retired or unemployed, what was the last occupation before retiring or becoming unemployed)?

Q79 Please, indicate the level of education completed by the child's FATHER:

O Primary education (Grade School) (1)

Secondary education (High School) (2)

University or college education (3)

Post-graduate education (4)

None of the above (5)

Q80 Please, indicate in which country or region was the father born?

Q81 What is the child's father's occupation (or if retired or unemployed, what was the last occupation before retiring or becoming unemployed)?

Q80 Information about your child's health.

Q81 Was your child born prematurely?

$\mathrm{O}$ Yes (1)

No (2)

Q82 Do you have any concerns about your child's language? (If 'yes', please explain briefly)

Y Yes (1)

No (2)

Q84 Has your child ever undergone speech or language therapy? (If 'yes', please explain briefly)

Y Yes (1)

No (2) 
Q85 Has your child ever been treated for a hearing problem? (If 'yes', please explain briefly)

O Yes (1)

O No (2)

Q83 How old was your child when s/he spoke his/her first word?

Q79 Who answered this questionnaire? What is your relationship with the child?

Q86 Thank you very much for your time and cooperation! 


\section{Appendix 2}

Portuguese background questionnaire

Q46 Questionário sobre a linguagem da sua criança

(Para ser respondido pela pessoa que passa o maior tempo com a criança)

Questionário adaptado a partir do trabalho de Gathercole et al.

Gathercole, Virginia C. Mueller, Thomas, Enlli Môn, Jones, Leah, Viñas Guasch, Nestor, Young, Nia, \& Hughes, Emma K. (2010)

Stadthagen-González, Hans, Gathercole, Virginia C. Mueller, Pérez-Tattam, Rocío, \& Yavas, Feryal. (2013)

Gathercole, Virginia C. Mueller, Thomas, Enlli Môn, Roberts, Emily, Hughes, Catrin, \& Hughes, Emma K. (2013)

Pérez-Tattam, Rocío, Gathercole, Virginia C. Mueller, Yavas, Feryal, Stadthagen-

González, Hans, \& Anrrich, Graciela. (2013)

Q47 Eu ficarei muito grata se você, por gentileza, puder responder ao seguinte questionário sobre experiência de linguagem e outras informações relevantes. As informações obtidas serão úteis neste estudo. Por favor, sinta-se à vontade em deixar qualquer dos itens em branco se você preferir não respondê-los.

Nome da criança (1)

Data de nascimento da criança (2)

Local de nascimento da criança (3)

Q48 Ordem de nascimento:

$1^{\circ}$ filho/a (mais velho/a) (1)

$2^{o}$ filho/a (2)

$3^{\circ}$ filho/a (3)

$4^{\mathrm{o}}$ filho/a (4)

$5^{\circ}$ filho/a (5)

$6^{\circ}$ filho/a (6)

Q49 Informação para contato de um dos pais:

Nome: (1)

Email: (2)

Telefone: (3)

Q50 Sua criança é:

Menino (1)

Menina (2) 
Q51 Sua criança nasceu nos Estados Unidos da América?

$\operatorname{Sim}(1)$

Não (2)

Q52 Se sua criança não nasceu nos Estados Unidos:

Com que idade ele/a se mudou para os Estados Unidos? (1)

Há quanto tempo ele/a mora nos Estados Unidos? (2)

Não se aplica (3)

Q53 Por favor, indique os lugares onde sua criança morou por períodos de tempo significativos (pelo menos um ano): Exemplo.:

Lugar e data: São Paulo, Brasil; 2012-14

Lugar e data: New York City, NY; 2014-15

Lugar e data: Miami, FL; 2015

Lugar e data: (1)

Lugar e data: (2)

Lugar e data: (3)

Q54 Uso da língua na infância: Qual(is) das línguas abaixo sua criança fala?

(Escolha todas que se aplicam)

Português (1)

Inglês (2)

Outra língua (3)

Q55 Se sua criança fala Português, quando ela começou a falar essa língua?

quando bebê (1)

com 1 ano (2)

com 2 anos (3)

Não se aplica (4)

Q56 Se sua criança fala Inglês, quando ela começou a falar essa língua?

quando bebê (1)

com 1 ano (2)

com 2 anos (3)

Não se aplica (4)

Q57 Se sua criança fala outra língua, que não Português ou Inglês:

Que língua? (1)

Ela começou a falar essa língua por volta da idade? (2)

Q58 Que língua(s) a mãe e/ou o pai da criança fala/falou com a criança EM CASA desde o nascimento até hoje? 


\begin{tabular}{|c|c|c|c|c|c|c|c|c|}
\hline & $\begin{array}{l}\text { Praticame } \\
\text { nte } 100 \% \\
\text { Inglês (1) }\end{array}$ & $\begin{array}{c}\text { Cerca } \\
\text { de } 80 \% \\
\text { Inglês; } \\
20 \% \\
\text { Portugu } \\
\text { ês (2) }\end{array}$ & $\begin{array}{c}\text { Cerca } \\
\text { de } 60 \% \\
\text { Inglês; } \\
40 \% \\
\text { Portugu } \\
\text { ês (3) }\end{array}$ & $\begin{array}{c}\text { Cerca } \\
\text { de } 50 \% \\
\text { Inglês; } \\
50 \% \\
\text { Portugu } \\
\text { ês (4) }\end{array}$ & $\begin{array}{c}\text { Cerca } \\
\text { de } 40 \% \\
\text { Inglês; } \\
60 \% \\
\text { Portugu } \\
\text { ês (5) }\end{array}$ & $\begin{array}{c}\text { Cerca } \\
\text { de } 20 \% \\
\text { Inglês, } \\
80 \% \\
\text { Portugu } \\
\text { ês (6) }\end{array}$ & $\begin{array}{c}\text { Praticame } \\
\text { nte } 100 \% \\
\text { Português } \\
\text { (7) }\end{array}$ & $\begin{array}{c}\mathrm{N} / \\
\mathrm{A} \\
(8)\end{array}$ \\
\hline $\begin{array}{l}\text { Mã } \\
\text { e } \\
(1)\end{array}$ & 2 & 3 & 4 & 5 & 6 & 7 & 8 & 9 \\
\hline $\begin{array}{l}\text { Pai } \\
\text { (2) }\end{array}$ & 10 & 11 & 12 & 13 & 14 & 15 & 16 & 17 \\
\hline
\end{tabular}

Q59 Que língua(s) a criança fala/falou com sua mãe e/ou seu pai ANTES de começar a frequentar uma creche? (Se relevante)

\begin{tabular}{|c|c|c|c|c|c|c|c|c|}
\hline & $\begin{array}{c}\text { Cerca } \\
\text { de } 80 \%\end{array}$ & $\begin{array}{c}\text { Cerca } \\
\text { de } 60 \%\end{array}$ & $\begin{array}{c}\text { Cerca } \\
\text { de 50\% }\end{array}$ & $\begin{array}{c}\text { Cerca } \\
\text { de } 40 \%\end{array}$ & $\begin{array}{c}\text { Cerca } \\
\text { de } 20 \%\end{array}$ & Praticame & N/ \\
nte 100\% & $\begin{array}{c}\text { Inglês; } \\
\text { Inglês (1) }\end{array}$ & $\begin{array}{c}\text { Inglês; } \\
\text { Portugu } \\
\text { ês (2) }\end{array}$ & $\begin{array}{c}\text { Inglês; } \\
\text { Portugu } \\
\text { ês (3) }\end{array}$ & $\begin{array}{c}\text { Inglês; } \\
\text { Portugu } \\
\text { ês (4) }\end{array}$ & $\begin{array}{c}\text { Inglês, } \\
\text { Portugu } \\
\text { ês (5) }\end{array}$ & $\begin{array}{c}\text { nte } 100 \% \\
\text { Portugu } \\
\text { ês (6) }\end{array}$ & $\begin{array}{c}\text { Português } \\
\text { A }\end{array}$ & $\begin{array}{c}\text { A } \\
(8)\end{array}$ \\
\hline $\begin{array}{c}\text { Mã } \\
\text { e } \\
(1)\end{array}$ & 18 & 19 & 20 & 21 & 22 & 23 & 24 & 25 \\
$\begin{array}{c}\text { Pai } \\
(2)\end{array}$ & 26 & 27 & 28 & 29 & 30 & 31 & 32 & 33 \\
\hline
\end{tabular}

Q60 Que língua(s) a criança fala/falou com sua mãe e/ou seu pai DEPOIS de começar a frequentar uma creche? (Se relevante)

\begin{tabular}{|c|c|c|c|c|c|c|c|c|}
\hline & $\begin{array}{l}\text { Praticame } \\
\text { nte } 100 \% \\
\text { Inglês (1) }\end{array}$ & $\begin{array}{c}\text { Cerca } \\
\text { de } 80 \% \\
\text { Inglês; } \\
20 \% \\
\text { Portugu } \\
\text { ês }(2)\end{array}$ & $\begin{array}{c}\text { Cerca } \\
\text { de } 60 \% \\
\text { Inglês; } \\
40 \% \\
\text { Portugu } \\
\text { ês (3) }\end{array}$ & $\begin{array}{c}\text { Cerca } \\
\text { de } 50 \% \\
\text { Inglês; } \\
50 \% \\
\text { Portugu } \\
\text { ês (4) }\end{array}$ & $\begin{array}{c}\text { Cerca } \\
\text { de } 40 \% \\
\text { Inglês; } \\
60 \% \\
\text { Portugu } \\
\text { ês (5) }\end{array}$ & $\begin{array}{c}\text { Cerca } \\
\text { de } 20 \% \\
\text { Inglês, } \\
80 \% \\
\text { Portugu } \\
\text { ês (6) }\end{array}$ & $\begin{array}{c}\text { Praticame } \\
\text { nte } 100 \% \\
\text { Português } \\
\quad(7)\end{array}$ & $\begin{array}{l}\mathrm{N} / \\
\mathrm{A} \\
(8)\end{array}$ \\
\hline $\begin{array}{l}\text { Mã } \\
\text { e } \\
(1)\end{array}$ & 34 & 35 & 36 & 37 & 38 & 39 & 40 & 41 \\
\hline $\begin{array}{l}\text { Pai } \\
\text { (2) }\end{array}$ & 42 & 43 & 44 & 45 & 46 & 47 & 48 & 49 \\
\hline
\end{tabular}

Q61 Que língua(s) os/as irmãos/irmãs mais novos(as) e mais velhos(as) falam com a criança? (Se relevante) 


\begin{tabular}{|c|c|c|c|c|c|c|c|c|}
\hline & $\begin{array}{c}\text { Praticam } \\
\text { ente } \\
100 \% \\
\text { Inglês (1) }\end{array}$ & $\begin{array}{c}\text { Cerca } \\
\text { de } \\
80 \% \\
\text { Inglês; } \\
20 \% \\
\text { Portug } \\
\text { uês (2) }\end{array}$ & $\begin{array}{c}\text { Cerca } \\
\text { de } \\
60 \% \\
\text { Inglês; } \\
40 \% \\
\text { Portug } \\
\text { uês (3) }\end{array}$ & $\begin{array}{c}\text { Cerca } \\
\text { de } \\
50 \% \\
\text { Inglês; } \\
50 \% \\
\text { Portug } \\
\text { uês (4) }\end{array}$ & $\begin{array}{c}\text { Cerca } \\
\text { de } \\
40 \% \\
\text { Inglês; } \\
60 \% \\
\text { Portug } \\
\text { uês (5) }\end{array}$ & $\begin{array}{c}\text { Cerca } \\
\text { de } \\
20 \% \\
\text { Inglês, } \\
80 \% \\
\text { Portug } \\
\text { uês (6) }\end{array}$ & $\begin{array}{c}\text { Praticam } \\
\text { ente } \\
100 \% \\
\text { Portuguê } \\
\text { s (7) }\end{array}$ & $\begin{array}{l}\mathrm{N} / \\
\mathrm{A} \\
(8)\end{array}$ \\
\hline $\begin{array}{l}\text { Irmã(o } \\
\text { s) mais } \\
\text { novos( } \\
\text { as) } \\
\text { com a } \\
\text { criança } \\
\text { (1) }\end{array}$ & 50 & 51 & 52 & 53 & 54 & 55 & 56 & 57 \\
\hline $\begin{array}{c}\text { Irmã(o } \\
\text { s) mais } \\
\text { velhos( } \\
\text { as) } \\
\text { com a } \\
\text { criança } \\
\text { (2) }\end{array}$ & 58 & 59 & 60 & 61 & 62 & 63 & 64 & 65 \\
\hline
\end{tabular}

Q63 Que língua(s) a criança fala com os/as irmãos/irmãs mais novos e mais velhos? (Se relevante)

\begin{tabular}{|c|c|c|c|c|c|c|c|c|}
\hline & $\begin{array}{c}\text { Praticam } \\
\text { ente } \\
100 \% \\
\text { Inglês (1) }\end{array}$ & $\begin{array}{c}\text { Cerca } \\
\text { de } \\
80 \% \\
\text { Inglês; } \\
20 \% \\
\text { Portug } \\
\text { uês (2) }\end{array}$ & $\begin{array}{l}\text { Cerca } \\
\text { de } \\
60 \% \\
\text { Inglês; } \\
40 \% \\
\text { Portug } \\
\text { uês (3) }\end{array}$ & $\begin{array}{c}\text { Cerca } \\
\text { de } \\
50 \% \\
\text { Inglês; } \\
50 \% \\
\text { Portug } \\
\text { uês (4) }\end{array}$ & $\begin{array}{l}\text { Cerca } \\
\text { de } \\
40 \% \\
\text { Inglês; } \\
60 \% \\
\text { Portug } \\
\text { uês (5) }\end{array}$ & $\begin{array}{c}\text { Cerca } \\
\text { de } \\
20 \% \\
\text { Inglês, } \\
80 \% \\
\text { Portug } \\
\text { uês (6) }\end{array}$ & $\begin{array}{c}\text { Praticam } \\
\text { ente } \\
100 \% \\
\text { Portuguê } \\
\text { s (7) }\end{array}$ & $\begin{array}{c}\mathrm{N} / \\
\mathrm{A} \\
(8)\end{array}$ \\
\hline $\begin{array}{l}\text { Crianç } \\
\text { a com } \\
\text { irmã(os } \\
\text { ) mais } \\
\text { novos( } \\
\text { as) (1) }\end{array}$ & 66 & 67 & 68 & 69 & 70 & 71 & 72 & 73 \\
\hline $\begin{array}{c}\text { Crianç } \\
\text { a com } \\
\text { irmã(os } \\
\text { ) mais } \\
\text { velhos( } \\
\text { as) (2) }\end{array}$ & 74 & 75 & 76 & 77 & 78 & 79 & 80 & 81 \\
\hline
\end{tabular}


Q64 Há algum(a) outro(a) adulto(a) importante (avós, tios, tias, etc...) com quem a criança tenha contato frequente?

$82 \operatorname{Sim}(1)$

83 Não (2)

Q65 Se sim, responda às perguntas a seguir:

Q66 Adulto 1 Por favor, especifique a relação deste adulto com sua criança:

Q67 Adulto 1 Qual(is) língua(s) essa pessoa fala com sua criança?

84 Sempre Inglês (1)

85 Sempre Português (2)

86 Às vezes Inglês, às vezes Português (3)

87 Outra (4)

Q68 Adulto 1 Com que frequência sua criança vê essa pessoa?

88 Todos os dias (1)

89 Pelo menos uma vez por semana (2)

90 Cerca de uma vez por mês (3)

91 Duas ou três vezes por ano (4)

92 Com menos frequência (5)

Q70 Adulto 2 Por favor, especifique a relação deste adulto com sua criança:

Q71 Adulto 2 Qual(is) língua(s) essa pessoa fala com sua criança?

93 Sempre Inglês (1)

94 Sempre Português (2)

95 Às vezes Inglês, às vezes Português (3)

96 Outra (4)

Q69 Adulto 2 Com que frequência sua criança vê essa pessoa?

97 Todos os dias (1)

98 Pelo menos uma vez por semana (2)

99 Cerca de uma vez por mês (3)

100Duas ou três vezes por ano (4)

101 Com menos frequência (5)

Q72 Com quem a criança passa a maior parte do dia?

102Mãe (1)

103Pai (2)

104Avós (3)

105Babá (4)

106Outro (5)

Q73 Creche 
Outras línguas? Por favor, especifique:

Q74 Com amigos

No geral, qual é a língua que sua criança fala com os amigos(as)?

\begin{tabular}{|c|c|c|c|c|c|c|c|c|}
\hline & $\begin{array}{c}\text { Praticam } \\
\text { ente } \\
100 \% \\
\text { Inglês (1) }\end{array}$ & $\begin{array}{c}\text { Cerca } \\
\text { de } \\
80 \% \\
\text { Inglês; } \\
20 \% \\
\text { Portug } \\
\text { uês (2) }\end{array}$ & $\begin{array}{c}\text { Cerca } \\
\text { de } \\
60 \% \\
\text { Inglês; } \\
40 \% \\
\text { Portug } \\
\text { uês (3) }\end{array}$ & $\begin{array}{c}\text { Cerca } \\
\text { de } \\
50 \% \\
\text { Inglês; } \\
50 \% \\
\text { Portug } \\
\text { uês (4) }\end{array}$ & $\begin{array}{c}\text { Cerca } \\
\text { de } \\
40 \% \\
\text { Inglês; } \\
60 \% \\
\text { Portug } \\
\text { uês (5) }\end{array}$ & $\begin{array}{c}\text { Cerca } \\
\text { de } \\
20 \% \\
\text { Inglês, } \\
80 \% \\
\text { Portug } \\
\text { uês (6) }\end{array}$ & $\begin{array}{c}\text { Praticam } \\
\text { ente } \\
100 \% \\
\text { Portuguê } \\
\text { s (7) }\end{array}$ & $\begin{array}{c}\mathrm{N} / \\
\mathrm{A} \\
(8)\end{array}$ \\
\hline $\begin{array}{c}\text { Com } \\
\text { amigos( } \\
\text { as) (1) }\end{array}$ & 107 & 108 & 109 & 110 & 111 & 112 & 113 & 114 \\
\hline
\end{tabular}

Q75 Com amigos(as) Outras línguas? Por favor, especifique:

Q76 Informações gerais

Por favor, indique o nível de escolaridade completo pela MÃE da criança:

115Ensino Fundamental (Primeiro Grau) (1)

116Ensino Médio (Segundo Grau) (2)

117Ensino Superior (Universidade) (3)

118 Ensino de Pós-Graduação (4)

119 Nenhuma das alternativas (5)

Q77 Por favor, indique em que país ou região a mãe da criança nasceu?

Q78 Qual é a ocupação/profissão da mãe? (Se aposentada ou se não estiver trabalhando, qual foi a última ocupação antes de se aposentar ou parar de trabalhar?)

Q79 Por favor, indique o nível de escolaridade completo pelo PAI da criança:

120Ensino Fundamental (Primeiro Grau) (1)

121Ensino Médio (Segundo Grau) (2)

122Ensino Superior (Universidade) (3)

123 Ensino de Pós-Graduação (4)

124Nenhuma das alternativas (5)

Q80 Por favor, indique em que país ou região o pai da criança nasceu?

Q81 Qual é a ocupação/profissão do pai? (Se aposentado ou se não estiver trabalhando, qual foi a última ocupação antes de se aposentar ou parar de trabalhar?) 
Q82 Informações sobre a saúde da criança.

Q83 A sua criança nasceu antes dos 9 meses?

$125 \operatorname{Sim}(1)$

126Não (2)

Q82 Você tem alguma preocupação em relação à linguagem de sua criança? (Se você responder "sim", por favor, dê uma breve explicação.)

$127 \operatorname{Sim}(1)$

128Não (2)

Q84 Sua criança já foi submetida à terapia de fala ou de linguagem? (Se você responder "sim", por favor, dê uma breve explicação.)

129Sim (1)

130Não (2)

Q85 Sua criança já teve que ser tratada por algum problema de audição? (Se você responder "sim", por favor, dê uma breve explicação.)

131Sim (1)

132Não (2)

Q83 Com que idade sua criança falou a primeira palavra?

Q84 Quem respondeu a este questionário? Qual sua relação com a criança?

Q86 Muito obrigada pelo seu tempo e pela sua colaboração! 


\section{Appendix 3}

Translation Equivalents - Cognates

\begin{tabular}{|c|c|c|c|}
\hline & Translation Equivalents & & \\
\hline & Cognates & & \\
\hline & & Portuguese & English \\
\hline & Sound Effects & & \\
\hline 1 & & grrrrrrrr & grrrr \\
\hline 2 & & miau & meow \\
\hline 3 & & muu & moo \\
\hline \multirow[t]{2}{*}{4} & & qua qua / quen quen & quack-quack \\
\hline & Animals & & \\
\hline 5 & & elefante & elephant \\
\hline 6 & & girafa & giraffe \\
\hline 7 & & leão & lion \\
\hline 8 & & pinguin & penguin \\
\hline \multirow[t]{2}{*}{9} & & zebra & zebra \\
\hline & Vehicles & & \\
\hline 10 & & carro & car \\
\hline 11 & & helicóptero & helicopter \\
\hline 12 & & trator & tractor \\
\hline \multirow[t]{2}{*}{13} & & trem & train \\
\hline & Toys & & \\
\hline \multirow[t]{2}{*}{14} & & bola & ball \\
\hline & Clothing & & \\
\hline 15 & & bota & boots \\
\hline 16 & & botão & button \\
\hline 17 & & pijamas & pajamas \\
\hline 18 & & short & shorts \\
\hline \multirow[t]{2}{*}{19} & & suéter & sweater \\
\hline & Body parts & & \\
\hline 20 & & pênis & penis \\
\hline
\end{tabular}




\begin{tabular}{|c|c|c|c|}
\hline 21 & & vagina & vagina \\
\hline & Food/drink & & \\
\hline 22 & & banana & banana \\
\hline 23 & & café & coffee \\
\hline 24 & & cereal & cereal \\
\hline 25 & & chocolate & chocolate \\
\hline 26 & & coca-cola & coke \\
\hline 27 & & geléia & jelly \\
\hline 28 & & hambúrguer & hamburger \\
\hline 29 & & iogurte & yogurt \\
\hline 30 & & laranja & orange \\
\hline 31 & & pizza & pizza \\
\hline 32 & & pudim & pudding \\
\hline 33 & & sal & salt \\
\hline 34 & & sanduíche & sandwich \\
\hline 35 & & sopa & soup \\
\hline \multirow[t]{2}{*}{36} & & vitamina & vitamin \\
\hline & Places to go & & \\
\hline 37 & & circo & circus \\
\hline 38 & & escola & school \\
\hline \multirow[t]{2}{*}{39} & & parque & park \\
\hline & Outside things & & \\
\hline \multirow[t]{2}{*}{40} & & flor & flower \\
\hline & Furniture and rooms & & \\
\hline 41 & & garagem & garage \\
\hline \multirow[t]{2}{*}{42} & & tv & tv \\
\hline & Household items & & \\
\hline 43 & & papel & paper \\
\hline 44 & & planta & plant \\
\hline 45 & & prato & plate \\
\hline 46 & & telefone & telephone \\
\hline & Games/routines & & \\
\hline
\end{tabular}




\begin{tabular}{|r|l|l|l|}
\hline $\mathbf{4 7}$ & & alô & hello \\
\hline $\mathbf{4 8}$ & & não & no \\
\hline & & & \\
\hline $\mathbf{4 9}$ & People & polícia & police \\
\hline & & & \\
\hline & Action Words & & dance \\
\hline $\mathbf{5 0}$ & & dançar & \\
\hline & & & \\
\hline
\end{tabular}




\section{Appendix 4}

Non-problematic non-cognates Translation Equivalents

\begin{tabular}{|c|c|c|c|}
\hline & Translation Equivalents & & \\
\hline & Non-Cognates & & \\
\hline & & Portuguese & English \\
\hline & Sound effects & & \\
\hline 1 & & ai! & ouch \\
\hline 2 & & au-au! & woof woof \\
\hline 3 & & cocorocococó & cockadoodledoo \\
\hline 4 & & mééé & baa baa \\
\hline & Animals & & \\
\hline 5 & & abelha & bee \\
\hline 6 & & bicho & animal \\
\hline 7 & & borboleta & butterfly \\
\hline 8 & & burro & donkey \\
\hline 9 & & cachorro & $\operatorname{dog}$ \\
\hline 10 & & carneiro & lamb \\
\hline 11 & & cavalo & horse \\
\hline 12 & & coelho & bunny \\
\hline 13 & & formiga & ant \\
\hline 14 & & galo & rooster \\
\hline 15 & & gato & cat \\
\hline 16 & & jacaré & alligator \\
\hline 17 & & lobo & wolf \\
\hline 18 & & macaco & monkey \\
\hline 19 & & passarinho & bird \\
\hline 20 & & pato & duck \\
\hline 21 & & peixe & fish \\
\hline 22 & & peru & turkey \\
\hline 23 & & porco & pig \\
\hline 24 & & rato & mouse \\
\hline 25 & & sapo & frog \\
\hline 26 & & tartaruga & turtle \\
\hline 27 & & urso & bear \\
\hline
\end{tabular}




\begin{tabular}{|c|c|c|c|}
\hline 28 & & vaca & cow \\
\hline & Vehicles & & \\
\hline 29 & & avião & airplane \\
\hline 30 & & barco & boat \\
\hline 31 & & caminhão & truck \\
\hline 32 & & carrinho de bebê & stroller \\
\hline 33 & & carro de bombeiro & firetruck \\
\hline 34 & & moto & motorcycle \\
\hline \multirow[t]{2}{*}{35} & & ônibus & bus \\
\hline & Toys & & \\
\hline 36 & & boneca & doll \\
\hline 37 & & brinquedo & toy \\
\hline 38 & & caneta & pen \\
\hline 39 & & cola & glue \\
\hline 40 & & lápis (de cor) & pencil \\
\hline 41 & & livro & book \\
\hline \multirow[t]{2}{*}{42} & & massa & play dough \\
\hline & Clothing & & \\
\hline 43 & & babador & bib \\
\hline 44 & & calça & pants \\
\hline 45 & & camisa/camiseta & shirt \\
\hline 46 & & casaco & coat \\
\hline 47 & & chapéu & hat \\
\hline 48 & & chinelo/sandália & slipper \\
\hline 49 & & cinto & belt \\
\hline 50 & & colar & necklace \\
\hline 51 & & fralda & diaper \\
\hline 52 & & meia & sock \\
\hline 53 & & relógio (de pulso) & watch \\
\hline 54 & & sapato & shoe \\
\hline 55 & & tênis & sneaker \\
\hline \multirow[t]{2}{*}{56} & & vestido & dress \\
\hline & Body parts & & \\
\hline 57 & & barriga & tummy \\
\hline
\end{tabular}




\begin{tabular}{|c|c|c|c|}
\hline 58 & & boca & mouth \\
\hline 59 & & bochecha & cheek \\
\hline 60 & & braço & arm \\
\hline 61 & & bumbum & buttocks/bottom \\
\hline 62 & & cabeça & head \\
\hline 63 & & cabelo & hair \\
\hline 64 & & dente & tooth \\
\hline 65 & & joelho & knee \\
\hline 66 & & língua & tongue \\
\hline 67 & & mão & hand \\
\hline 68 & & nariz & nose \\
\hline 69 & & olho & eye \\
\hline 70 & & ombro & shoulder \\
\hline 71 & & pé & feet \\
\hline 72 & & perna & leg \\
\hline 73 & & queixo & chin \\
\hline 74 & & rosto & face \\
\hline \multirow[t]{2}{*}{75} & & umbigo & belly button \\
\hline & Food and Drink & & \\
\hline 76 & & água & water \\
\hline 77 & & batata & potato \\
\hline 78 & & biscoito & cookie \\
\hline 79 & & bolacha & cracker \\
\hline 80 & & bolo & cake \\
\hline 81 & & carne & meat \\
\hline 82 & & cenoura & carrots \\
\hline 83 & & chiclete & gum \\
\hline 84 & & comida & food \\
\hline 85 & & doce & candy \\
\hline 86 & & feijão & beans \\
\hline 87 & & galinha & chicken \\
\hline 88 & & gelo & ice \\
\hline 89 & & leite & milk \\
\hline 90 & & maçã & apple \\
\hline 91 & & manteiga & butter \\
\hline 92 & & milho & corn \\
\hline 93 & & morango & strawberry \\
\hline
\end{tabular}




\begin{tabular}{|c|c|c|c|}
\hline 94 & & ovo & egg \\
\hline 95 & & pão & bread \\
\hline 96 & & peixe & fish \\
\hline 97 & & picolé & popsicle \\
\hline 98 & & pipoca & popcorn \\
\hline 99 & & pirulito & lollipop \\
\hline 100 & & queijo & cheese \\
\hline 101 & & sorvete & ice cream \\
\hline 102 & & suco & juice \\
\hline 103 & & torrada & toast \\
\hline 104 & & uva & grapes \\
\hline & Places to go & & \\
\hline 105 & & casa & house \\
\hline 106 & & fazenda & farm \\
\hline 107 & & festa & party \\
\hline 108 & & floresta & woods \\
\hline 109 & & igreja & church \\
\hline 110 & & loja & store \\
\hline 111 & & posto (de gasolina) & gas station \\
\hline 112 & & praia & beach \\
\hline 113 & & trabalho & work \\
\hline 114 & & zoológico & zoo \\
\hline & Outside things & & \\
\hline 115 & & árvore & tree \\
\hline 116 & & balanço & swing \\
\hline 117 & & bandeira & flag \\
\hline 118 & & calçada/passeio & sidewalk \\
\hline 119 & & céu & sky \\
\hline 120 & & chuva & rain \\
\hline 121 & & escorregador(eira) & slide \\
\hline 122 & & grama & grass \\
\hline 123 & & lua & moon \\
\hline 124 & & mangueira & hose \\
\hline 125 & & nuvem & cloud \\
\hline 126 & & pá & shovel \\
\hline 127 & & piscina & pool \\
\hline
\end{tabular}




\begin{tabular}{|c|c|c|c|}
\hline 128 & & rua & street \\
\hline 129 & & sol & sun \\
\hline \multirow[t]{2}{*}{130} & & telhado & roof \\
\hline & Furniture and rooms & & \\
\hline 131 & & banco & bench \\
\hline 132 & & banheira & bathtub \\
\hline 133 & & banheiro & bathroom \\
\hline 134 & & berço & crib \\
\hline 135 & & cadeira & chair \\
\hline 136 & & cama & bed \\
\hline 137 & & chuveiro & shower \\
\hline 138 & & cozinha & kitchen \\
\hline 139 & & fogão & stove \\
\hline 140 & & gaveta & drawer \\
\hline 141 & & geladeira & refrigerator \\
\hline 142 & & guarda-roupa & closet \\
\hline 143 & & janela & window \\
\hline 144 & & máquina de lavar & washing machine \\
\hline 145 & & mesa & table \\
\hline 146 & & penico & potty \\
\hline 147 & & pia & $\operatorname{sink}$ \\
\hline 148 & & porta & door \\
\hline 149 & & sala & living room \\
\hline \multirow[t]{2}{*}{150} & & varanda & porch \\
\hline & Small household items & & \\
\hline 151 & & balde & bucket \\
\hline 152 & & bolsa & purse \\
\hline 153 & & caixa & box \\
\hline 154 & & chave & keys \\
\hline 155 & & cobertor/coberta & blanket \\
\hline 156 & & colher & spoon \\
\hline 157 & & copo & glass \\
\hline 158 & & dinheiro & money \\
\hline 159 & & escova & brush \\
\hline 160 & & escova de dente & toothbrush \\
\hline 161 & & faca & knife \\
\hline
\end{tabular}




\begin{tabular}{|c|c|c|c|}
\hline 162 & & garfo & fork \\
\hline 163 & & garrafa & bottle \\
\hline 164 & & guardanapo & napkin \\
\hline 165 & & lata & can \\
\hline 166 & & mamadeira & bottle \\
\hline 167 & & martelo & hammer \\
\hline 168 & & pente & comb \\
\hline 169 & & quadro & picture \\
\hline 170 & & relógio & clock \\
\hline 171 & & remédio & medicine \\
\hline 172 & & retrato/foto & picture \\
\hline 173 & & sabão/sabonete & soap \\
\hline 174 & & tesoura & scissors \\
\hline 175 & & toalha & towel \\
\hline 176 & & vassoura & broom \\
\hline \multirow[t]{2}{*}{177} & & xícara & cup \\
\hline & Games and Routines & & \\
\hline 178 & & almoço/comida & lunch \\
\hline 179 & & banho & bath \\
\hline 180 & & cala a boca & shh/shush \\
\hline 181 & & jantar & dinner \\
\hline 182 & & lanche/merenda & snack \\
\hline 183 & & obrigado & thank you \\
\hline 184 & & oi/olá & hi/hello \\
\hline 185 & & por favor & please \\
\hline 186 & & tchau & bye \\
\hline 187 & & vira! & turn around \\
\hline \multirow[t]{2}{*}{188} & & vou te pegar! & gonna get you \\
\hline & People & & \\
\hline 189 & & amiga/amigo & friend \\
\hline 190 & & babá & babysitter \\
\hline 191 & & nome da babá & babysitter's name \\
\hline 192 & & neném & baby \\
\hline 193 & & pai/papai & daddy \\
\hline 194 & & palhaço & clown \\
\hline 195 & & professora & teacher \\
\hline
\end{tabular}




\begin{tabular}{|c|c|c|c|}
\hline 196 & & o próprio nome & child's own name \\
\hline & Words about time & & \\
\hline 197 & & agora & now \\
\hline 198 & & amanhã & tomorrow \\
\hline 199 & & de noite & tonight \\
\hline 200 & & depois & after \\
\hline 201 & & de dia & day \\
\hline 202 & & hoje & today \\
\hline \multirow[t]{2}{*}{203} & & depressa/rápido & fast \\
\hline & Prepositions and Locations & & \\
\hline 204 & & aí & there \\
\hline 205 & & alí & there \\
\hline 206 & & aqui & here \\
\hline 207 & & atrás & behind \\
\hline 208 & & dentro & inside/in \\
\hline 209 & & do lado & beside \\
\hline 210 & & embaixo & under \\
\hline 211 & & fora & out \\
\hline 212 & & lá & over there \\
\hline 213 & & mais & more \\
\hline 214 & & perto & next to \\
\hline 215 & & também & too \\
\hline 216 & & tudo & all \\
\hline 217 & & com & with \\
\hline 218 & & de & of \\
\hline \multirow[t]{2}{*}{219} & & em & in/at \\
\hline & Action words & & \\
\hline 220 & & abrir & open \\
\hline 221 & & acabar & finish \\
\hline 222 & & ajudar & help \\
\hline 223 & & andar & walk \\
\hline 224 & & beber & drink \\
\hline 225 & & beijar & kiss \\
\hline 226 & & brincar & play \\
\hline 227 & & cair & fall \\
\hline
\end{tabular}




\begin{tabular}{|c|c|c|}
\hline 228 & cantar & sing \\
\hline 229 & carregar & carry \\
\hline 230 & chorar & cry \\
\hline 231 & chutar & kick \\
\hline 232 & cobrir & cover \\
\hline 233 & colocar/botar & put \\
\hline 234 & comer & eat \\
\hline 235 & comprar & buy \\
\hline 236 & consertar & fix \\
\hline 237 & correr & run \\
\hline 238 & cortar & cut \\
\hline 239 & dar & give \\
\hline 240 & dormir & sleep \\
\hline 241 & empurrar & push \\
\hline 242 & esconder (-se) & hide \\
\hline 243 & escrever & write \\
\hline 244 & esperar & wait \\
\hline 245 & fazer & make \\
\hline 246 & fechar & close \\
\hline 247 & ficar & stay \\
\hline 248 & ganhar & get \\
\hline 249 & gostar & like \\
\hline 250 & jogar & throw \\
\hline 251 & lavar & wash \\
\hline 252 & ler & read \\
\hline 253 & levantar (-se) & stand \\
\hline 254 & levar & take \\
\hline 255 & limpar & clean \\
\hline 256 & morder & bite \\
\hline 257 & mostrar & show \\
\hline 258 & nadar & swim \\
\hline 259 & olhar & look \\
\hline 260 & parar & stop \\
\hline 261 & pegar & catch \\
\hline 262 & pensar & think \\
\hline 263 & pular & jump \\
\hline 264 & puxar & pull \\
\hline 265 & quebrar & break \\
\hline
\end{tabular}




\begin{tabular}{|l|l|l|l|}
\hline 266 & & rasgar & rip/tear \\
\hline 267 & rir & smile \\
\hline 268 & segurar & hold \\
\hline 269 & subir & climb \\
\hline 270 & ter & have \\
\hline 271 & tocar & play \\
\hline 272 & tomar & drink \\
\hline 273 & trabalhar & work \\
\hline 274 & trazer & bring \\
\hline 275 & & varrer & sweep \\
\hline 276 & ver & see \\
\hline & & & \\
\hline 277 & Helping Verbs & & \\
\hline 278 & & estar & be \\
\hline 279 & ir & go \\
\hline 280 & podia & could \\
\hline 281 & & tem (têm) & has/have \\
\hline & & ter que & have \\
\hline & Descriptive words & & \\
\hline 282 & & & \\
\hline 283 & & acordado & awake \\
\hline 284 & & alto & high/loud \\
\hline 285 & & amarelo & yellow \\
\hline 286 & assustado & scared \\
\hline 287 & & azul & blue \\
\hline 288 & & branco & white \\
\hline 289 & bom & good \\
\hline 290 & bonito & pretty \\
\hline 291 & cansado & tired \\
\hline 292 & cheio & full \\
\hline 293 & difícil & hard \\
\hline 294 & doente/dodói & sick \\
\hline 295 & duro & hard \\
\hline 296 & escuro & dark \\
\hline 297 & frio & cold \\
\hline 298 & grande & big \\
\hline 299 & lento/devagar & slow \\
\hline & limpo & \\
\hline & & \\
\hline
\end{tabular}




\begin{tabular}{|c|c|c|c|}
\hline 300 & & lindo & cute \\
\hline 301 & & mau & bad \\
\hline 302 & & melhor & better \\
\hline 303 & & molhado & wet \\
\hline 304 & & pesado & heavy \\
\hline 305 & & preto & black \\
\hline 306 & & primeiro & first \\
\hline 307 & & quente & hot \\
\hline 308 & & quebrado & broken \\
\hline 309 & & rápido & fast \\
\hline 310 & & seco & dry \\
\hline 311 & & sujo & dirty \\
\hline 312 & & triste & sad \\
\hline 313 & & vazio & empty \\
\hline 314 & & velho & old \\
\hline 315 & & verde & green \\
\hline \multirow[t]{2}{*}{316} & & vermelho & red \\
\hline & Question words & & \\
\hline 317 & & o que & what \\
\hline 318 & & por que & why \\
\hline 319 & & qual & which \\
\hline 320 & & quando & when \\
\hline \multirow[t]{3}{*}{321} & & quem & who \\
\hline & Quantifiers and articles & & \\
\hline & Pronouns & & \\
\hline 322 & & a gente & we \\
\hline 323 & & aquela/aquele & that \\
\hline 324 & & aquilo & that \\
\hline 325 & & esse/essa & this \\
\hline 326 & & eu & I \\
\hline 327 & & isso & this \\
\hline 328 & & seu/sua teu/tua & your \\
\hline 329 & & te & you \\
\hline 330 & & tu/você & you \\
\hline
\end{tabular}




\begin{tabular}{|l|l|l|l|}
\hline & Connecting Words & & \\
\hline 331 & aí & and then/so \\
\hline 332 & e & and \\
\hline 333 & então & so/then \\
\hline 334 & mas & but \\
\hline 335 & porque & because \\
\hline 336 & que & that \\
\hline 337 & se & if \\
\hline & & & \\
\hline
\end{tabular}




\section{Appendix 5}

Translation Equivalents - Uncertain: list of words that were considered uncertain in order to be put in the Cognates category.

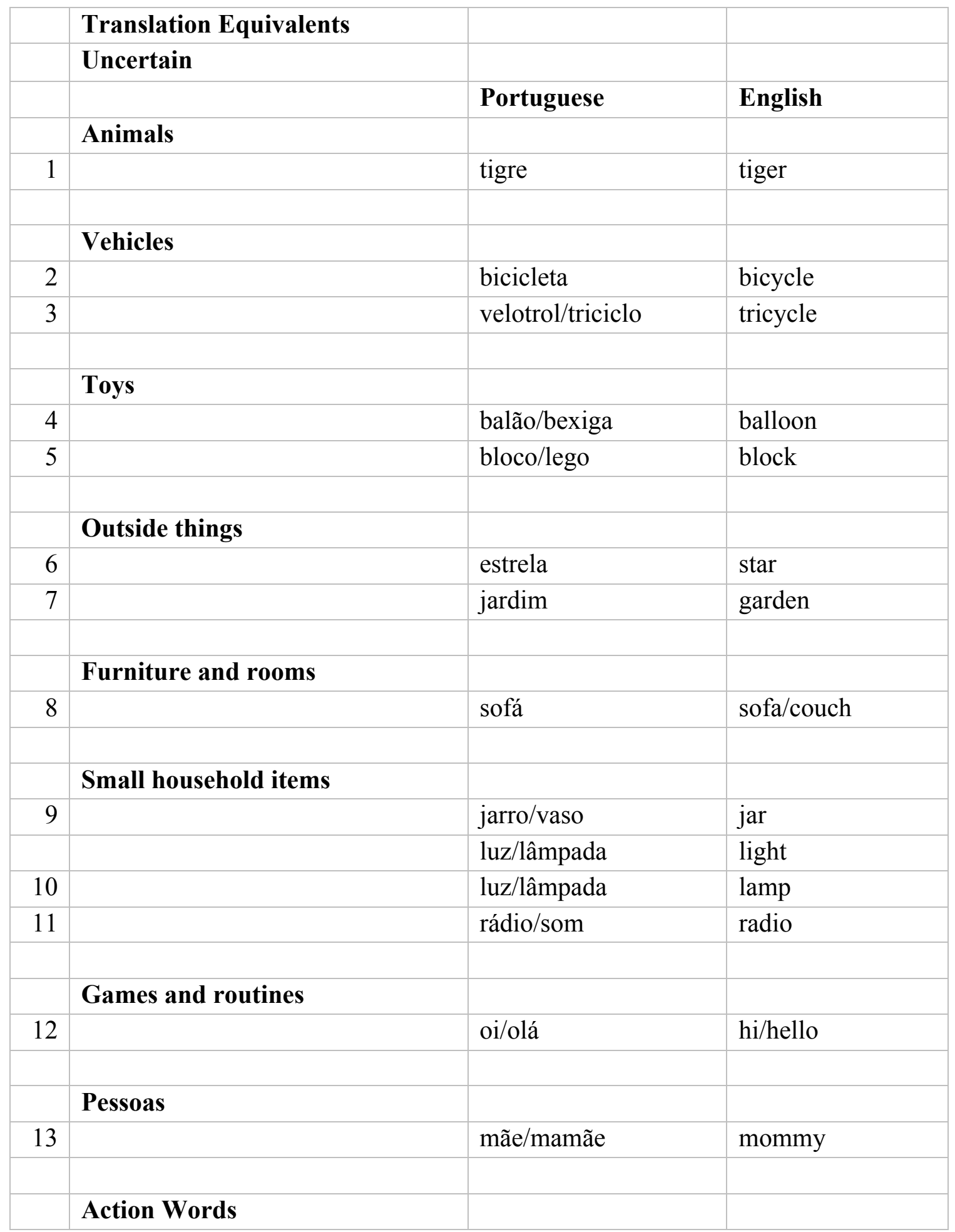




\begin{tabular}{|r|l|l|l|}
\hline 14 & & desenhar/pintar & draw/paint \\
\hline 15 & & sentar (-se) & sit \\
\hline & & & \\
\hline 16 & Descriptive Words & & new \\
\hline & & novo & \\
\hline & Prepositions & & for/by \\
\hline 17 & & por & \\
\hline
\end{tabular}




\section{Appendix 6}

List of 'problematic' words that were subtracted from the Total Vocabulary to establish the Total Modified Vocabulary.

Words from the Translation Equivalents - Non-cognates

\begin{tabular}{|c|c|c|}
\hline & Portuguese & English \\
\hline \multirow[t]{2}{*}{1} & \multirow[t]{2}{*}{ Galinha } & Chicken \\
\hline & & Hen \\
\hline \multirow[t]{2}{*}{2} & Calcinha & \multirow[t]{2}{*}{ Underpants } \\
\hline & Cueca & \\
\hline \multirow[t]{2}{*}{3} & \multirow[t]{2}{*}{ Dedo } & Finger \\
\hline & & Toe \\
\hline \multirow[t]{2}{*}{4} & Orelha & \multirow[t]{2}{*}{ Ear } \\
\hline & Ouvido & \\
\hline \multirow[t]{2}{*}{5} & \multirow[t]{2}{*}{ Quintal } & Backyard \\
\hline & & Yard \\
\hline \multirow[t]{2}{*}{6} & \multirow[t]{2}{*}{ Pedra } & Rock \\
\hline & & Stone \\
\hline \multirow[t]{2}{*}{7} & \multirow[t]{2}{*}{ Escada } & Stairs \\
\hline & & Ladder \\
\hline \multirow[t]{2}{*}{8} & \multirow[t]{2}{*}{ Quarto } & Bedroom \\
\hline & & Room \\
\hline \multirow[t]{2}{*}{9} & Almofada & \multirow[t]{2}{*}{ Pillow } \\
\hline & Travesseiro & \\
\hline \multirow[t]{2}{*}{10} & \multirow[t]{2}{*}{ Lixo/lixeira } & Trash \\
\hline & & Garbage \\
\hline \multirow[t]{2}{*}{11} & \multirow[t]{2}{*}{ Avó/Avô } & Grandmother \\
\hline & & Grandfather \\
\hline \multirow[t]{2}{*}{12} & \multirow[t]{2}{*}{ Irmã/irmão } & Sister \\
\hline & & Brother \\
\hline \multirow[t]{2}{*}{13} & \multirow[t]{2}{*}{ Menino/Menina } & Boy \\
\hline & & Girl \\
\hline \multirow[t]{2}{*}{14} & \multirow[t]{2}{*}{ Tio/tia } & Uncle \\
\hline & & Aunt \\
\hline \multirow[t]{2}{*}{15} & \multirow[t]{2}{*}{ Em cima } & On \\
\hline & & On top of \\
\hline 16 & Muito & A lot \\
\hline & & Much \\
\hline 17 & Outro & Another \\
\hline & & Other \\
\hline 18 & Para & To \\
\hline
\end{tabular}




\begin{tabular}{|c|c|c|}
\hline & & For \\
\hline \multirow[t]{3}{*}{19} & Bater & Bump \\
\hline & & Hit \\
\hline & & Knock \\
\hline \multirow[t]{2}{*}{20} & Dizer/falar & Say \\
\hline & & Talk \\
\hline \multirow[t]{2}{*}{21} & Desenhar/pintar & Draw \\
\hline & & Paint \\
\hline \multirow[t]{2}{*}{22} & Escutar/Ouvir & Listen \\
\hline & & Hear \\
\hline \multirow[t]{2}{*}{23} & Pequeno & Little \\
\hline & & Tiny \\
\hline \multirow[t]{2}{*}{24} & Onde & Where \\
\hline & Cadê & \\
\hline \multirow[t]{4}{*}{25} & A & The \\
\hline & $\mathrm{O}$ & \\
\hline & As & \\
\hline & Os & \\
\hline \multirow[t]{2}{*}{26} & Um & $\mathrm{A} / \mathrm{An}$ \\
\hline & Uma & \\
\hline \multirow[t]{2}{*}{27} & Ele/ela & $\mathrm{He}$ \\
\hline & & She \\
\hline \multirow[t]{2}{*}{28} & Meu/minha & My \\
\hline & & Mine \\
\hline \multirow[t]{2}{*}{29} & $\mathrm{Me}$ & me \\
\hline & $\operatorname{mim}$ & \\
\hline \multirow[t]{2}{*}{30} & é & Is \\
\hline & (es)tá & \\
\hline \multirow[t]{3}{*}{31} & (es)tamos & Are \\
\hline & (es)tão & \\
\hline & são & \\
\hline \multirow[t]{2}{*}{32} & (es)tou & Am \\
\hline & sou & \\
\hline \multirow[t]{3}{*}{33} & pode & Can \\
\hline & podemos & \\
\hline & posso & \\
\hline \multirow[t]{3}{*}{34} & quer & \\
\hline & querem & wanna/want to \\
\hline & quero & \\
\hline \multirow[t]{2}{*}{35} & temos & \\
\hline & tenho & have \\
\hline \multirow[t]{3}{*}{36} & Vai & \\
\hline & Vamos & gonna/goingo to \\
\hline & Vão & \\
\hline
\end{tabular}




\section{Appendix 7}

List of words from the Brazilian-Portuguese version of the CDI with no Translation Equivalent in the English CDI.

\begin{tabular}{|c|c|c|}
\hline $\begin{array}{l}\text { No Translation } \\
\text { Equivalents }\end{array}$ & & \\
\hline & Portuguese CDI & English meaning \\
\hline \multicolumn{3}{|l|}{ Sound effects } \\
\hline & bibi & beep \\
\hline & piu-piu & cheep-cheep \\
\hline & toc-toc & knock-knock \\
\hline & trimm & sound of a phone ringing \\
\hline \multicolumn{3}{|l|}{ Animals } \\
\hline & aranha & spider \\
\hline & baleia & whale \\
\hline & barata & cockroach \\
\hline & boi & bull \\
\hline & caranguejo & crab \\
\hline & cobra & snake \\
\hline & hipopótamo & hippopotamus \\
\hline & lagartixa & gecko \\
\hline & mosca & fly \\
\hline & mosquito & mosquito \\
\hline & onça & jaguar \\
\hline & tubarão & shark \\
\hline \multicolumn{3}{|l|}{ Vehicles } \\
\hline & ambulância & ambulance \\
\hline & carro de polícia & police car \\
\hline & navio & ship \\
\hline & patins & rollerblades \\
\hline \multicolumn{3}{|l|}{ Toys } \\
\hline & espada & sword \\
\hline & pião & whipping-top \\
\hline
\end{tabular}




\begin{tabular}{|c|c|c|}
\hline & tambor & drum \\
\hline \multicolumn{3}{|l|}{ Clothing } \\
\hline & argola & hoop \\
\hline & blusa & blouse \\
\hline & bico/chupeta & pacifier \\
\hline & bolsa & purse \\
\hline & boné & cap \\
\hline & camisola & nightdress \\
\hline & guarda-chuva & umbrella \\
\hline & óculos & glasses \\
\hline & pulseira & bracelet \\
\hline & roupa & clothing \\
\hline & saia & skirt \\
\hline \multicolumn{3}{|l|}{ Body } \\
\hline & cara & face (colloquial) \\
\hline & cocô & poo \\
\hline & costas & back \\
\hline & garganta & throat \\
\hline & peito & chest/breast \\
\hline & unha & nail \\
\hline & xixi & pee \\
\hline \multicolumn{3}{|l|}{ Food and drink } \\
\hline & açúcar & sugar \\
\hline & amendoim & peanut \\
\hline & arroz & rice \\
\hline & bala & hard candy \\
\hline & bombom & chocolate candy \\
\hline & brigadeiro & $\begin{array}{l}\text { traditional brazilian dessert for } \\
\text { birthdays }\end{array}$ \\
\hline & cachorro-quente & hot dog \\
\hline & goiabada & guava paste \\
\hline & guaraná & traditional brazilian soda \\
\hline & macarrão & pasta \\
\hline & mamão & papaya \\
\hline & melancia & watermelon \\
\hline
\end{tabular}




\begin{tabular}{|c|c|c|}
\hline & mingau & porridge \\
\hline & nescau & nesquick \\
\hline & salgadinho & salty brazilian fingerfood \\
\hline & tangerina & tangerine \\
\hline & torta & pie, cake (birthday cake) \\
\hline & verdura & greenery \\
\hline \multicolumn{3}{|l|}{ Places to go } \\
\hline & cinema & movie theater \\
\hline & clube & club/ recreation center \\
\hline & feira & fair \\
\hline & hospital/médico & hospital/doctor \\
\hline & mercado & market/supermarket \\
\hline & shopping & mall \\
\hline \multicolumn{3}{|l|}{ Outside things } \\
\hline & areia & sand \\
\hline & buraco & hole \\
\hline & elevador & elevator \\
\hline & muro & wall \\
\hline & placa & plaque, (traffic) sign \\
\hline & planta & plant \\
\hline & trovão/trovoada & thunder \\
\hline \multicolumn{3}{|l|}{ Furniture and rooms } \\
\hline & armário & cabinet \\
\hline & corredor & hall \\
\hline \multicolumn{3}{|l|}{ Small household items } \\
\hline & computador & computer \\
\hline & mamadeira & baby bottle \\
\hline & sacola & bag/plastic bag \\
\hline & ventilador & fan \\
\hline \multicolumn{3}{|l|}{ Games and routines } \\
\hline & achei! & found it \\
\hline & beijinhos & kisses \\
\hline & (vamos em)bora? & let's go \\
\hline
\end{tabular}




\begin{tabular}{|c|c|c|}
\hline & cosquinhas & tickles \\
\hline & cadê? & where is it? \\
\hline & dá um abraço & give me a hug \\
\hline & dá um pedaço & give me a piece \\
\hline & dá susto & scare! \\
\hline & licença & excuse me \\
\hline & muito bem! & good job/well done \\
\hline & nana neném & lullaby song in Portuguese \\
\hline & saúde! & bless you! \\
\hline & sono! & sleepy! \\
\hline & tira & take it off \\
\hline & tudo bom? & everything good? \\
\hline \multicolumn{3}{|l|}{ People } \\
\hline & empregada & housekeeper \\
\hline & madrinha/dinda & godmother \\
\hline & padrinho/dindo & godfather \\
\hline & primo/prima & cousin \\
\hline \multicolumn{3}{|l|}{ Words about time } \\
\hline \multicolumn{3}{|l|}{ Prepositions/Locations } \\
\hline & assim & so/thus/like this \\
\hline & bem & well \\
\hline & já & already/now \\
\hline & na frente & in front of \\
\hline & $\begin{array}{l}\text { outra vez/de } \\
\text { novo }\end{array}$ & again \\
\hline & pouco & little (quantity) \\
\hline \multicolumn{3}{|l|}{ Action words } \\
\hline & abaixar & lower/go down \\
\hline & amarrar & tie \\
\hline & apagar & erase/turn off \\
\hline & arrumar & organize \\
\hline & $\begin{array}{l}\text { chover } \\
\text { (chovendo) }\end{array}$ & rain (raining) \\
\hline & chupar & suck \\
\hline
\end{tabular}




\begin{tabular}{|c|c|c|}
\hline & deitar & lay down \\
\hline & dobrar & fold \\
\hline & doer & hurt/ache \\
\hline & entrar & go inside/enter \\
\hline & gritar & scream/yell \\
\hline & juntar & join/put together \\
\hline & ligar & turn on/call (on the phone) \\
\hline & passear & walk around \\
\hline & pentear-se & comb \\
\hline & perder & loose \\
\hline & prender & arrest/aprehend \\
\hline & procurar & look for/search for \\
\hline & queimar & burn \\
\hline & querer & want \\
\hline & saber & know \\
\hline & sair & go out/leave \\
\hline & soltar & let go/release \\
\hline & tampar & close with a lid \\
\hline & tirar & take off \\
\hline & trocar & change/exchange \\
\hline & vestir-se & get dress \\
\hline & vir & come \\
\hline \multicolumn{3}{|l|}{ Helping verbs } \\
\hline \multicolumn{3}{|l|}{ Descriptive words } \\
\hline & bobo & silly \\
\hline & diferente & different \\
\hline & feio & ugly \\
\hline & forte & strong \\
\hline & fraco & weak \\
\hline & gordo & fat \\
\hline & igual & equal/same \\
\hline & mole & soft/flaccid/opposite of hard \\
\hline & rasgado & ripped/torn \\
\hline Question words & & \\
\hline & & \\
\hline
\end{tabular}




\begin{tabular}{|l|l|l|}
\hline Quantifiers and articles & & \\
\hline Pronouns & & \\
\hline & & \\
\hline Connecting words & & \\
\hline & ou & or \\
\hline & por causa de & on account of/because of \\
\hline & & \\
\hline
\end{tabular}




\section{Appendix 8}

List of words from the English version of the CDI with no Translation Equivalent in the Brazilian-Portuguese CDI.

\begin{tabular}{|c|c|c|}
\hline $\begin{array}{l}\text { No Translation } \\
\text { Equivalents }\end{array}$ & & \\
\hline & English CDI & Portuguese meaning \\
\hline \multicolumn{3}{|l|}{ Sound effects } \\
\hline & choo choo & tchu-tchu \\
\hline & uh oh & o-oh \\
\hline & vroom & vrum \\
\hline & yum yum & hummm \\
\hline \multicolumn{3}{|l|}{ Animals } \\
\hline & deer & cervo \\
\hline & goose & ganso \\
\hline & kitty & gatinho \\
\hline & moose & alce \\
\hline & owl & coruja \\
\hline & pony & pônei \\
\hline & puppy & cachorrinho \\
\hline & sheep & ovelha \\
\hline & squirrel & esquilo \\
\hline & teddybear & urso de pelúcia \\
\hline & hen & galinha \\
\hline & bug & inseto \\
\hline \multicolumn{3}{|l|}{ Vehicles } \\
\hline & sled & trenó \\
\hline \multicolumn{3}{|l|}{ Toys } \\
\hline & bat & taco \\
\hline & bubbles & bolhas de sabão \\
\hline & chalk & giz \\
\hline & game & jogo \\
\hline & crayon & giz de cera \\
\hline
\end{tabular}




\begin{tabular}{|c|c|c|}
\hline & present & presente \\
\hline & puzzle & quebra-cabeça \\
\hline & story & estória \\
\hline \multicolumn{3}{|l|}{ Clothing } \\
\hline & beads & miçangas \\
\hline & gloves & luvas \\
\hline & jeans & calça jeans \\
\hline & jacket & jaqueta \\
\hline & mittens & luvas de bebê \\
\hline & scarf & cachecol \\
\hline & snowsuit & roupa de neve \\
\hline & tights & meia-calça \\
\hline & zipper & zíper/fecho \\
\hline \multicolumn{3}{|l|}{ Body parts } \\
\hline & ankle & tornozelo \\
\hline & lips & lábios \\
\hline & owie/boo boo & machucado/dodói \\
\hline \multicolumn{3}{|l|}{ Food and drink } \\
\hline & applesauce & mingau de maçã \\
\hline & cheerios & type of cereal \\
\hline & donut & rosquinha frita \\
\hline & drink & bebida \\
\hline & french fries & batata frita \\
\hline & green beans & vagem \\
\hline & jello & gelatina \\
\hline & melon & melão \\
\hline & muffin & mufin/bolinho \\
\hline & noodles & massa instantânea \\
\hline & nuts & nozes \\
\hline & pancake & panqueca \\
\hline & peanut butter & manteiga de amendoim \\
\hline & peas & ervilha \\
\hline & pickle & pepino em conserva \\
\hline & potato chip & batata chips \\
\hline & pretzel & pretzel \\
\hline
\end{tabular}




\begin{tabular}{|c|c|c|}
\hline & pumpkin & abóbora \\
\hline & raisin & uva-passa \\
\hline & soda/pop & refrigerante \\
\hline & tuna & atum \\
\hline & vanilla & baunilha \\
\hline & spaghetti & espaguete \\
\hline & sauce & molho \\
\hline \multicolumn{3}{|l|}{ Places to go } \\
\hline & camping & acampamento \\
\hline & country & interior da cidade/país \\
\hline & downtown & centro da cidade \\
\hline & home & lar \\
\hline & movie & filme \\
\hline & outside & fora de casa \\
\hline & picnic & piquenique \\
\hline & playground & parque infantil \\
\hline \multicolumn{3}{|l|}{ Outside things } \\
\hline & lawn mower & cortador de grama \\
\hline & sandbox & caixa de areia \\
\hline & snow & neve \\
\hline & snowman & boneco de neve \\
\hline & sprinkler & borrifador \\
\hline & stick & pau/pauzinho \\
\hline & wind & vento \\
\hline \multicolumn{3}{|l|}{ Furniture and rooms } \\
\hline & basement & porão \\
\hline & dryer & secadora \\
\hline & high chair & cadeirão/cadeira alta de criança \\
\hline & oven & forno \\
\hline & playpen & cercado \\
\hline & rocking chair & cadeira de balanço \\
\hline \multicolumn{3}{|l|}{ Small household items } \\
\hline & basket & cesto \\
\hline & bowl & tigela \\
\hline
\end{tabular}




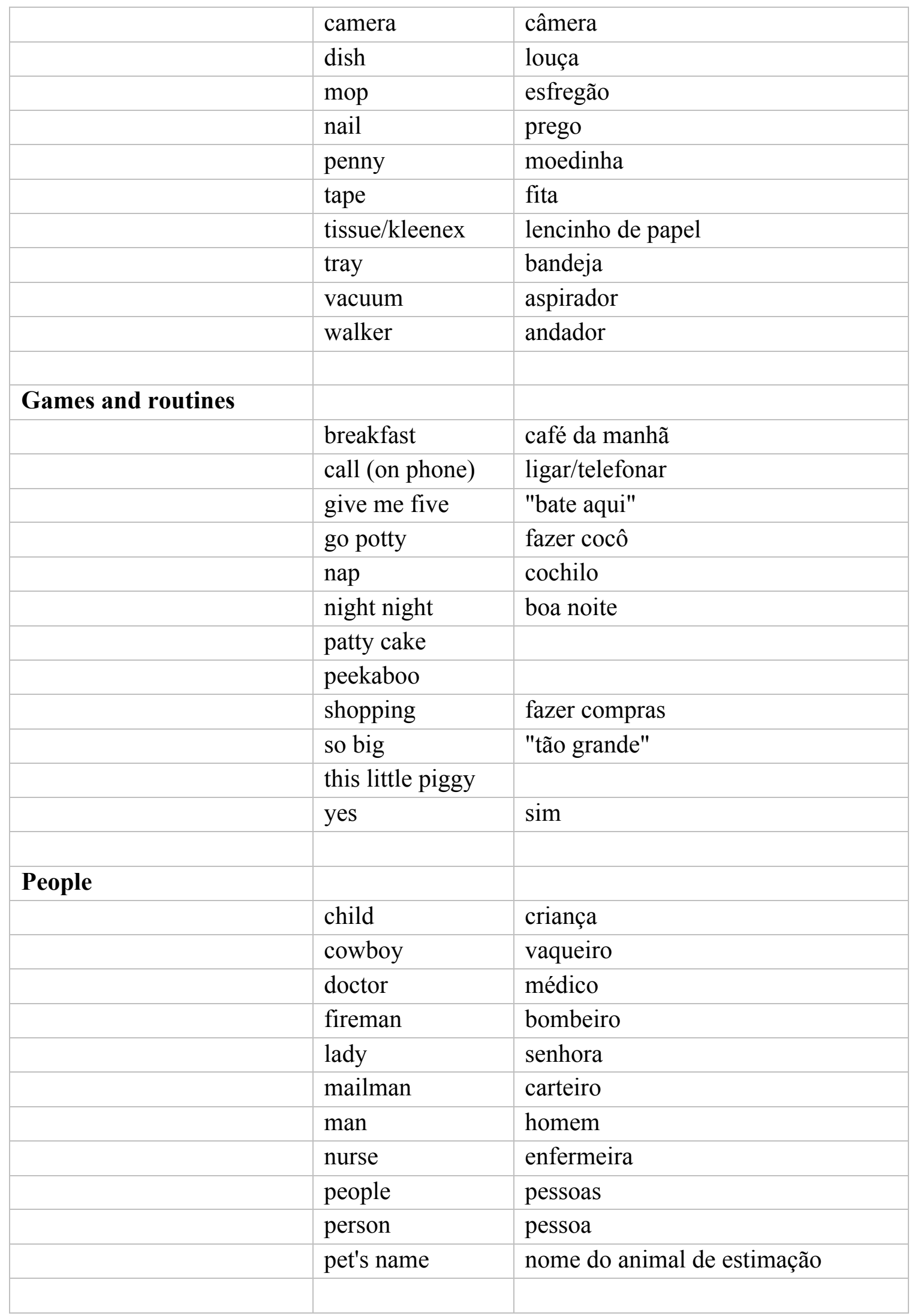




\begin{tabular}{|c|c|c|}
\hline \multicolumn{3}{|l|}{ Words about time } \\
\hline & before & antes \\
\hline & later & depois \\
\hline & morning & manhã \\
\hline & night & noite \\
\hline & time & tempo \\
\hline & yesterday & ontem \\
\hline \multicolumn{3}{|c|}{ Prepositions/Locations } \\
\hline & about & sobre \\
\hline & above & acima \\
\hline & around & ao redor \\
\hline & away & longe/ausente \\
\hline & back & de volta \\
\hline & down & para baixo \\
\hline & into & para dentro de \\
\hline & off & for a \\
\hline & over & sobre/acima \\
\hline & up & para cima \\
\hline \multicolumn{3}{|l|}{ Action words } \\
\hline & blow & soprar \\
\hline & build & construir \\
\hline & chase & perseguir \\
\hline & clap & aplaudir \\
\hline & cook & cozinhar \\
\hline & drive & dirigir \\
\hline & drop & derrubar \\
\hline & dry & secar \\
\hline & dump & despejar/descarregar \\
\hline & feed & alimentar \\
\hline & find & encontrar \\
\hline & fit & servir \\
\hline & hate & odiar \\
\hline & hug & abraçar \\
\hline & hurry & apressar \\
\hline & lick & lamber \\
\hline & love & amar \\
\hline
\end{tabular}




\begin{tabular}{|c|c|c|}
\hline & pick & escolher \\
\hline & pour & derramar/despejar \\
\hline & pretend & fingir \\
\hline & ride & montar/pegar carona \\
\hline & shake & sacudir/agitar \\
\hline & share & dividir/compartilhar \\
\hline & skate & patinar/andar de skate ou patins \\
\hline & slide & escorregar (no escorregador) \\
\hline & spill & derramar/entornar \\
\hline & splash & espalhar água' \\
\hline & swing & balançar \\
\hline & taste & provar \\
\hline & tickle & fazer cócegas \\
\hline & touch & encostar \\
\hline & wake & acordar \\
\hline & watch & assistir \\
\hline & wipe & limpar com um paninho \\
\hline & wish & desejar/pedir \\
\hline \multicolumn{3}{|l|}{ Helping verbs } \\
\hline & $\mathrm{did} /$ did ya & Você fez ...? \\
\hline & do & \\
\hline & does & \\
\hline & don't & Não \\
\hline & gotta/got to & tenho que \\
\hline & lemme/let me & deixe-me \\
\hline & need/need to & precisar \\
\hline & try/try to & tentar \\
\hline & was & era/estava \\
\hline & were & era/estava \\
\hline & will & -ei (verb ending) \\
\hline & would & -ia (verb ending) \\
\hline \multicolumn{3}{|l|}{ Descriptive words } \\
\hline & allgone & ido/sumido \\
\hline & asleep & adormecido \\
\hline & brown & marrom \\
\hline & careful & cuidadoso \\
\hline
\end{tabular}




\begin{tabular}{|c|c|c|}
\hline & fine & bem \\
\hline & gentle & suave/delicado \\
\hline & happy & feliz \\
\hline & hungry & com fome \\
\hline & hurt & machucado \\
\hline & last & último \\
\hline & long & longo/comprido \\
\hline & $\mathrm{mad}$ & bravo/zangado \\
\hline & naughty & malcriado/desobediente \\
\hline & nice & legal \\
\hline & noisy & barulhento \\
\hline & poor & pobre \\
\hline & quiet & quieto \\
\hline & sleepy & sonolento \\
\hline & soft & macio \\
\hline & sticky & grudento/pegajoso \\
\hline & stuck & preso \\
\hline & thirsty & com sede \\
\hline & windy & ventoso \\
\hline & yucky & nojento \\
\hline \multicolumn{3}{|c|}{ Question words } \\
\hline & how & como \\
\hline \multicolumn{3}{|c|}{ Quantifiers and articles } \\
\hline & any & qualquer \\
\hline & each & cada \\
\hline & every & cada/todos \\
\hline & more & mais \\
\hline & much & muito/bastante \\
\hline & not & não \\
\hline & none & nenhum \\
\hline & same & mesmo \\
\hline & some & algum/alguns \\
\hline \multicolumn{3}{|l|}{ Pronouns } \\
\hline & her & ela $(\mathrm{ACC})$ \\
\hline & hers & dela \\
\hline
\end{tabular}




\begin{tabular}{|l|l|l|}
\hline & him & ele (ACC) \\
\hline & his & dele \\
\hline & myself & mim mesmo/a \\
\hline & our & nosso \\
\hline & their & deles/delas \\
\hline & them & eles (ACC) \\
\hline & these & esses/estes \\
\hline & they & eles \\
\hline & those & aqueles/aquelas \\
\hline & us & nós (ACC) \\
\hline & yourself & você mesmo/a \\
\hline & & \\
\hline Connecting words & & \\
\hline & & \\
\hline
\end{tabular}

